University of Rhode Island

DigitalCommons@URI

Open Access Dissertations

1986

\title{
Anatomical and Morphological Response of Highbush Blueberry to Flooding Stress
}

John David Abbott

University of Rhode Island

Follow this and additional works at: https://digitalcommons.uri.edu/oa_diss

\section{Recommended Citation}

Abbott, John David, "Anatomical and Morphological Response of Highbush Blueberry to Flooding Stress" (1986). Open Access Dissertations. Paper 386.

https://digitalcommons.uri.edu/oa_diss/386

This Dissertation is brought to you for free and open access by DigitalCommons@URI. It has been accepted for inclusion in Open Access Dissertations by an authorized administrator of DigitalCommons@URI. For more information, please contact digitalcommons-group@uri.edu. 
University of Rhode Island

\section{DigitalCommons@URI}

Open Access Master's Theses

1986

\section{Anatomical ad Morphological Response of Highbush Blueberry to Flooding Stress}

John David Abbott

Follow this and additional works at: http://digitalcommons.uri.edu/theses

This Thesis is brought to you for free and open access by DigitalCommons@URI. It has been accepted for inclusion in Open Access Master's Theses by an authorized administrator of DigitalCommons@URI. For more information, please contact digitalcommons@etal.uri.edu. 
ANATOMICAL AND MORPHOLOGICAL RESPONSE OF HIGHBUSH BLUEBERRY TO FLOODING STRESS

BY

JOHN DAVID ABBOTT

A DISSERTATION SUBMITTED IN PARTIAL FULFILLMENT OF THE REQUIREMENTS FOR THE DEGREE OF DOCTOR OF PHILOSOPHY

IN

BIOLOGICAL SCIENCES

(PLANT SCIENCE) 
DOCTOR OF PHILOSOPHY DISSERTATION

OF

JOHN DAVID ABBOTT

Approved:

Dissertation Committee Major Professor
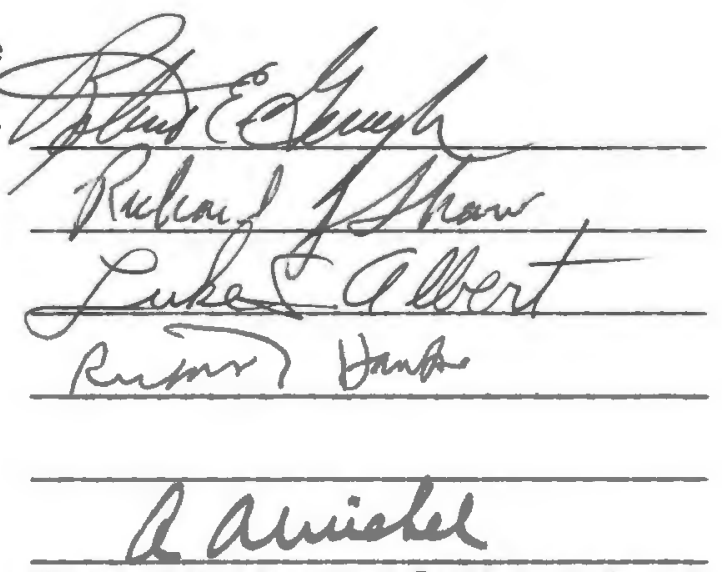

Dean of the Graduate School 
The purpose of this research was to study the various aspects of root, shoot and reproductive growth of the cultivated highbush blueberry under normal conditions and as influenced by seasonal root zone flooding.

These studies were conducted on three cultivars'Earliblue', 'Bluecrop', and 'Lateblue' for up to three years. Root, shoot, and reproductive growth were measured at intervals throughout the years and the soil temperature and stage of plant development recorded.

Growth of white unsuberized roots peaked in early-June and september when soil temperatures were in the range of 14 to $18^{\circ} \mathrm{C}$ and was concomitant with shoot growth.

Some plants survived more than 26 months of continuous flooding, but growth was decreased after approximately four months. April submerged plants had the greatest percentage of death followed by the August and December flooded plants. Vegetative and reproductive growth were greatly reduced with flooding. Anthesis was delayed by almost one week and fruit abscision was increased in flooded plants.

There was an increase in size of epidermal cells of roots from flooded plants. The mid-cortical cells of stems and spongy mesophyll complex of leaves from flooded plants had an increase in intercellular spaces. Flower buds from flooded plants were smaller in size and flower formation appeared delayed. 
DEDICATED TO CHRIS WITH LOVE 


\section{ACKNOWLEDGEMENTS}

The author expresses his sincere appreciation to $\mathrm{Dr}$. Robert E. Gough for his friendship, and his guidance and support of this research. Also, for his patience in reviewing the manuscripts. To committee members Drs. Richard J. Shaw, Luke S. Albert, and Richard L. Hauke, as well as Drs. Vladimir G. Shutak and John J. McGuire, I express my appreciation for their assistance and careful review of these manuscripts. I am grateful to: the East Farm crew for their timely assistance in maintaining the research plots; Dr. Walter C. Mueller for use of his critical point drier; Mr. David Browning, who provided valuable assistance in the preparation of the scanning electron micrographs; $\mathrm{Dr}$. Richard Koske for the use of his photomicrographic equipment; Mr. Peter Naumann for media analyses and Ms. Cheryl Blanck for typing these manuscripts.

The author would like to offer a special thanks to Sandra and James Briden, my in-laws, for providing a house for my family and me during my degree program.

The author would also like to mention his wife, Christine, whose years of support and patience, as well as self-sacrifice, made this all possible. 
This dissertation follows the manuscript format as approved by the Graduate School of the University of Rhode Island with modifications in style as required for publication in the specific scientific journals listed. Four manuscripts are included:

(1) Seasonal changes in the length of white unsuberized roots of the highbush blueberry under sawdust mulch (to be submitted to the Journal of the American Society for Horticultural Science);

(2) Vegetative growth survival of the highbush blueberry in response to flooding (to be submitted to the Journal of the American Society for Horticultural Science);

(3) Reproductive growth response of the highbush blueberry to flooding (to be submitted to HortScience);

(4) Anatomical response of the highbush blueberry to flooding (to be submitted to the Journal of the American Society for Horticultural Science). In addition, four appendices are included:

(1) Concluding remarks on the overall significance of the dissertation to an understanding of the growth and development of the highbush blueberry:

(2) Results ancillary to Manuscript I.;

(3) Results ancillary to Manuscript II.;

(4) Results ancillary to Manuscript III.; 
PAGE

DISSERTATION ABSTRACT................... ii

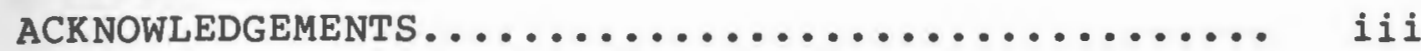

PREFACE.............................. iv

LIST OF TABLES.......................... vii

LIST OF FIGURES......................... ix

MANUSCRIPT I. SEASONAL CHANGES IN THE LENGTH OF WHITE UNSUBERIZED ROOTS OF THE HIGHBUSH BLUEBERRY UNDER SAWDUST MULCH......................

ABSTRACT............................... 2

INTRODUCTION............................ 3

MATERIALS AND METHODS...................... 4

RESULTS AND DISCUSSION.................... 5

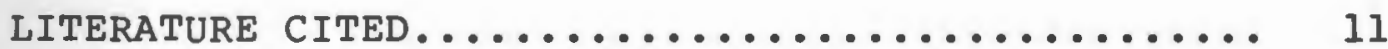

MANUSCRIPT II. VEGETATIVE GROWTH AND SURVIVAL OF THE HIGHBUSH BLUEBERRY IN RESPONSE TO FLOODING........... 20

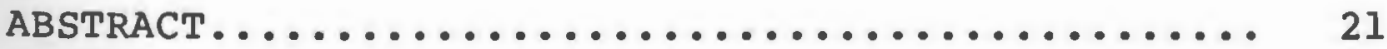

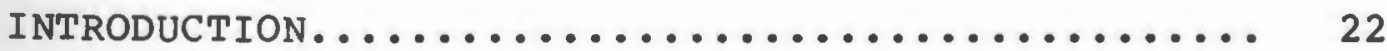

MATERIALS AND METHODS........................ 23

RESULTS AND DISCUSSION..................... 27

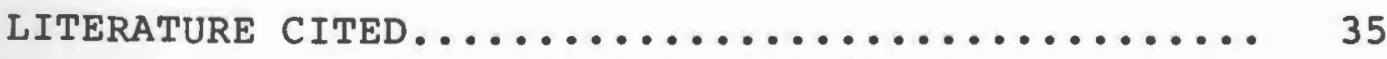

MANUSCRIPT III. REPRODUCTIVE GROWTH RESPONSE OF THE HIGHBUSH BLUEBERRY TO FLOODING........................ 50

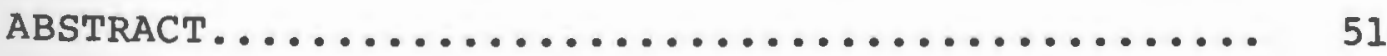

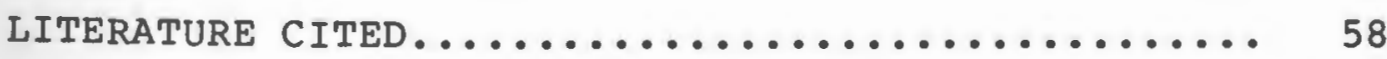


MANUSCRIPT IV. ANATOMICAL RESPONSE OF THE HIGHBUSH BLUEBERRY TO FLOODING...... 64

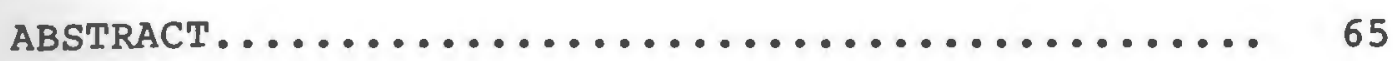

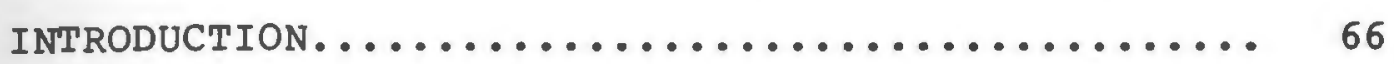

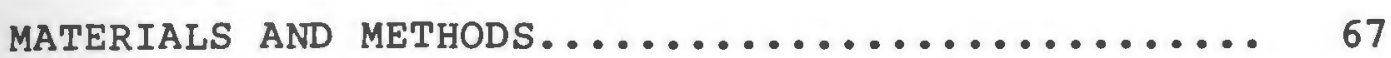

RESULTS AND DISCUSSION.............................. 68

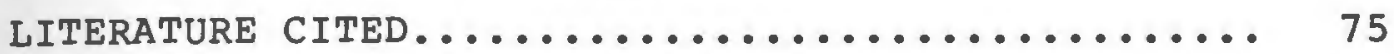

APPENDIX I. CONCLUDING REMARKS............... 98

APPENDIX II. RESULTS ANCILLARY TO MANUSCRIPT I.. 103

APPENDIX III. RESULTS ANCILLARY TO MANUSCRIPT II 110

APPENDIX IV. RESULTS ANCILLARY TO MANUSCRIPT III 113

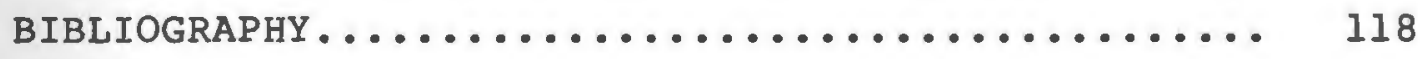


MANUSCRIPT II. VEGETATIVE GROWTH AND SURVIVAL OF THE

HIGHBUSH BLUEBERRY IN RESPONSE TO FLOODING

PAGE

TABLE 1. Shoot growth of flooded and control twoyear-old containerized 'Bluecrop' plants

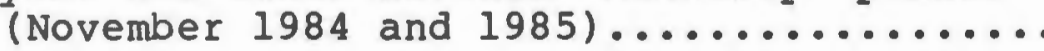

TABLE 2. Size of fully expanded leaves and percent open stomata from flooded and control two-year-old containerized 'Bluecrop' plants (17 June, 1985).................

TABLE 3. Shoot growth of flooded and control twoyear-old containerized 'Bluecrop' plants as affected by treatment date (Nov. 1984

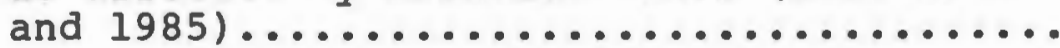

TABLE 4. Size of fully expanded leaves and percent open stomata from flooded and control two-year-old containerized 'Bluecrop' plants (17 June, 1985)................

MANUSCRIPT III. REPRODUCTIVE GROWTH. RESPONSE OF THE HIGHBUSH BLUEBERRY TO FLOODING

TABLE 1. Growth of flower buds and flowers from flooded and control two-year-old containerized 'Bluecrop' plants..........

TABLE 2. Reproductive growth of flooded and control two-year-old containerized 'Bluecrop' plants as affected by treatment date......

TABLE 3. Initial percent fruit set and percent fruit abscised from flooded and control two-year-old containerized 'Bluecrop'

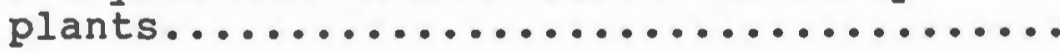

TABLE 4. Fruit weight, size and soluble solids from flooded and control two-year-old containerized 'Bluecrop' plants........... 
APPENDIX III. RESULTS ANCILLARY TO MANUSCRIPT II... 110

TABLE 1. Shoot growth of flooded and control twoyear-old containerized 'Bluecrop' plants as affected by treatment date (Nov. 1984). 111

TABLE 2. Shoot growth of flooded and control twoyear-old containerized 'Bluecrop' plants as affected by treatment date (Nov. 1985).

APPENDIX IV. RESULTS ANCILLARY TO MANUSCRIPT III...

TABLE 1. Reproductive growth of flooded and control two-year-old containerized 'Bluecrop' plants as affected by treatment date $(1984) \ldots \ldots \ldots \ldots \ldots \ldots \ldots$

TABLE 2. Reproductive growth of flooded and control two-year-old containerized 'Bluecrop' plants as affected by treatment date

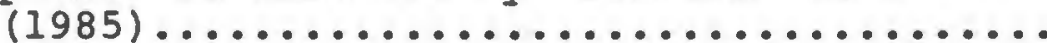

TABLE 3. Size of flower buds and flowers from flooded and control two-year-old containerized 'Bluecrop'plants as affected by treatment date........... 116

TABLE 4. Initial percent fruit set and cumulative percent fruit abscised from flooded and control two-year-old containerized 'Bluecrop' plants as affected by treatment date......................... 
MANUSCRIPT I. SEASONAL CHANGES IN THE LENGTH OF WHITE UNSUBERIZED ROOTS OF THE HIGHBUSH BLUEBERRY UNDER SAWDUST MULCH

FIGURE

PAGE

1. Elongation of white unsuberized roots of highbush blueberry in relation to soil temperature Vertical lines represent $\mathrm{SE} . \mathrm{SE}<1$ are not

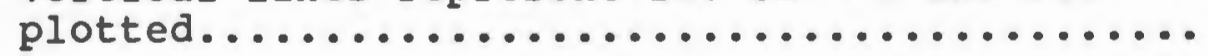

2. Relationship between mean length of white unsuberized roots and stage in development of

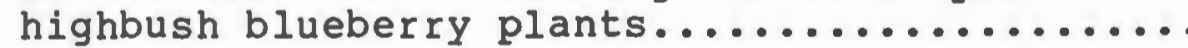

3. Relationship between mean length of white unsuberized roots and shoot growth of highbush blueberry plants. Vertical lines represent SE.

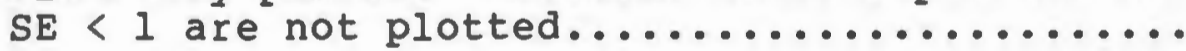

MANUSCRIPT II. VEGETATIVE GROWTH AND SURVIVAL OF THE HIGHBUSH BLUEBERRY IN RESPONSE TO FLOODING

1. Number of dead two-year-old containerized 'Bluecrop' plants over time as affected by

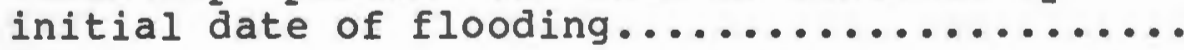

2. Temperature of the media water and air in the plant canopy in relation to the intensity of $2,3,5-t r i p h e n y l$ tetrazolium chloride stain (TTC) in roots from flooded two-year-old containerized 'Bluecrop' plants (1983-1984)....

3. Temperature of the media water and air in the plant canopy in relation to the intensity of $2,3,5$-triphenyl tetrazolium chloride stain (TTC) in roots from flooded two-year-old containerized 'Bluecrop' plants (1984-1985)....

4. Oxidation-reduction potential of the media from flooded and control two-year-old containerized 'Bluecrop' plants.......................

MANUSCRIPT IV. ANATOMICAL RESPONSE OF THE HIGHBUSH BLUEBERRY TO FLOODING 
1. Scanning electron photomicrograph of a cross section of a 'Bluecrop' blueberry root from a control plant. Scale bar=ll $\mathrm{km}$. Epidermis (E); Cortex (C); Endodermis (Ed); Stele (S)........

2. Scanning electron photomicrograph of a cross section of a 'Bluecrop' blueberry root from a flooded plant showing expanded epidermal cells, distorted cortex, and proliferated and crushed vascular tissue. Scale bar $=10 \mu \mathrm{m}$. Epidermis (E); Cortex (C); Stele (S)...................

3. Light micrograph of a cross section of a 'Bluecrop' blueberry root from a control plant. Scale bar $=42 \mu \mathrm{m}$. Epidermis (E); Cortex (C); Stele (S); Lateral $\operatorname{root}(\mathrm{L}) \ldots \ldots \ldots \ldots \ldots \ldots \ldots \ldots \ldots \ldots \ldots$

4. Light micrograph of a cross section of a 'Bluecrop' blueberry root from a flooded plant showing expanded epidermal cells, crushed cortex, and distorted vascular tissue. Scale bar= $70 \mu \mathrm{m}$. Epidermis (E); Cortex (C)............

5. Light micrograph of a cross section of a 'Bluecrop' blueberry stem from a control plant. Scale bar $=65 \mu \mathrm{m}$. Cuticle (Cu); Epidermis (E); Outer-cortex (0); Mid-cortex (M); Inner-

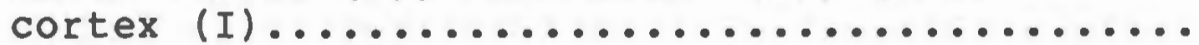

6. Light micrograph of a cross section of a 'Bluecrop' blueberry stem from a flooded plant showing large cortical air spaces. Scale bar= $69 \mu \mathrm{m}$. Cuticle (Cu); Epidermis (E); Outercortex (O); Mid-cortex (M); Inner-cortex (I)...

7. Light micrograph of a cross section of a 'Bluecrop' blueberry leaf blade from a control plant. Scale bar $=68 \mathrm{\mu m}$. Cuticle (C); Epidermis (E); Vascular tissue (V); Spongy mesophyll complex

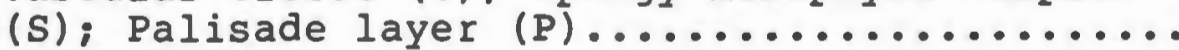

8. Light micrograph of a cross section of a 'Bluecrop' blueberry leaf blade from a flooded plant showing disrupted palisade layer and increased air spaces in the spongy mesophyll complex. Scale bar $=65 \mu \mathrm{m}$. Cuticle (C); Epidermis (E); Vascular tissue (V); Spongy mesophyll complex (S);

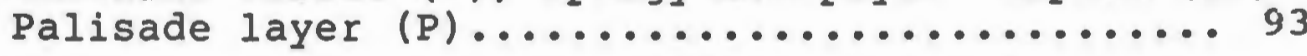

9. Light micrograph of a cross section of a 'Bluecrop' blueberry flower bud from a flooded plant. Scale 
bar $=150 \mu_{m} \ldots \ldots \ldots \ldots \ldots \ldots \ldots \ldots \ldots \ldots \ldots$

10. Light micrograph of a cross section of a 'Bluecrop' blueberry flower bud from a flooded plant. Note the delay in development and decreased overall size. Scale bar=171 $\mu$ m................... 97

APPENDIX II. RESULTS ANCILLARY TO MANUSCRIPT I

1. Elongation of white unsuberized roots of highbush blueberry in relation to soil temperature

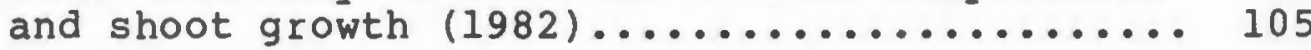

2. Elongation of white unsuberized roots of highbush blueberry in relation to soil temperature and shoot growth $(1983) \ldots \ldots \ldots \ldots \ldots \ldots \ldots \ldots . \ldots 10 \ldots \ldots$

3. Elongation of white unsuberized roots of highbush blueberry in relation to soil temperature

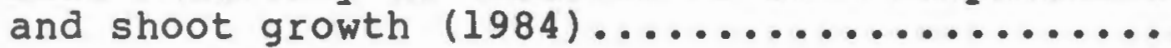


SEASONAL CHANGES IN THE LENGTH OF WHITE

UNSUBERIZED ROOTS OF THE HIGHBUSH BLUEBERRY

UNDER SAWDUST MULCH

MANUSCRIPT I 


\section{ABSTRACT}

Annual growth of white unsuberized roots from mature 'Earliblue', 'Bluecrop', and 'Lateblue' blueberry plants relative to soil temperatures, shoot growth, and stage of development was studied for three years. The growth of white unsuberized roots continued throughout the year, but was much reduced at soil temperatures below approximately $8^{\circ} \mathrm{C}$. Two peaks in the growth of white unsuberized roots occurred, the first in early June and the second, higher peak in September. Both peaks in root growth occurred with soil temperatures of 14 to $18^{\circ} \mathrm{C}$. The growth rate declined at soil temperatures outside this range. Growth of white unsuberized roots was concomitant with shoot growth. 
Little is known about the growth of roots in comparison to the growth of roots in comparison to the growth of the aerial parts of the plant (3). Root growth in general has been studied in a number of fruit-bearing species $(1,2,6,20)$ and factors such as temperature, season, and shoot growth were found to greatly influence growth of roots. Several researchers $(1,2,11,24)$ reported that a maximum rate of root growth in temperate zone woody plants occurs in the spring (May-June) and again in early autumn (September). Though root growth continued throughout the whole year $(2,6,9,24)$, minimum growth was found to occur in soil temperatures below $7-10^{\circ} \mathrm{C}$ and above $21^{\circ} \mathrm{C}(5,6,9,20)$. Optimum temperature for root growth is $15.5-18^{\circ} \mathrm{C}$ for many fruit-bearing plant $(20,24)$. A positive correlation between root and shoot growth for some species $(1,2,11)$ has been reported, although optimum temperature differs for each function $(5,19,24,27)$. Much of the work characterizing root growth has been conducted on tree fruits $(6,12,20,24)$. Except for a few studies, relatively little research has been done on root growth of bush fruits, especially the cultivated highbush blueberry $(1,2,4,8)$. Gough (8) reported that the highbush blueberry root system was shallow, fibrous, and restricted to the area within the drip line to a depth of $12-25 \mathrm{~cm}$. The purpose of this study was to characterize the growth of the unsuberized portion of the root system of the 
mature highbush blueberry plant, and how it may be influenced by soil temperature, shoot growth, and stage of plant development.

\section{Materials and Methods}

Three mature plants each of 'Earliblue', 'Bluecrop', and 'Lateblue' were grown on a Narragansett silt loam soil at a $\mathrm{pH}$ 4.8. Plants were spaced $1.8 \times 3.0 \mathrm{~m}$ and the entire area between and within rows was maintained under approximately 10-15 cm of sawdust mulch. The plants were not irrigated and each plant received an annual application of $1 \mathrm{~kg}$ of a $5 \mathrm{~N}: 4.3 \mathrm{P}: 8.3 \mathrm{~K}: 0.2 \mathrm{Mg}$ fertilizer. The plants were pruned in February of each year according to standard practices (7). Twenty-five dormant buds from each plant were selected randomly after pruning and each was tagged to monitor shoot growth on a 7-14 day basis throughout the growing season.

Root growth was inspected visually every 7-14 days throughout the year by carefully clearing away the sawdust mulch within the drip line to a depth of approximately 10-15 $\mathrm{cm}$, the depth at which the mulch meets the soil surface. Roots growing within the soil were not measured. The length of the new growth as indicated by white root tip tissue was measured to the nearest $0.5 \mathrm{~mm}$ using a mm ruler. Measurements were taken on 25 intact roots from each bush from March to December. The mulch was carefully replaced 
after root measurements were made. Root growth during January and February was inadequate to measure accurately. Soil/mulch interface temperatures were recorded daily at a depth of approximately $15 \mathrm{~cm}$ from the surface of the mulch. The mean date for each stage of development in the growth of the plants was recorded, including times of bud swell, bloom, and flower bud formation. The mean date for fruit set, stages of fruit ripening, and harvest were also recorded. Fruit were visually separated into stages of ripening. The immature green stage was determined when the largest berries had a dark green color over $100 \%$ of their surface. Blue-pink fruit were $75 \%$ blue and $25 \%$ pink and blue fruit were $90 \%$ blue and $10 \%$ pink. Data were collected for a period of 3 years beginning in 1982. Results were analyzed by an analysis of variance with plants within cultivars as replicates.

Results and Discussion

With slight differences, seasonal trends in root growth relative to soil temperature, shoot growth, and stage of development of the plant, remained consistent among cultivars and years. Therefore, the data presented here are a composite of 3 years' results.

From January to March the presence of white root-tips was observed, but extension growth was inadequate to measure accurately. Similar results were reported by researchers 
for other crops $(2,6,9,24)$. The limited growth of white root-tips at this time may be due to a very slow metabolic rate caused by colder temperatures which would reduce the rate of suberization, cell division, and extension growth in the root (6). A second explanation may be that the entire root growth ceased along with suberization before the latter engulfed the root-tip $(20,24)$. Rogers $(24)$ states that the rate of suberization in apple roots is about $1 / 4$ as great in cold weather as it is in warm weather. The soil temperature in our study from January to March was below $8^{\circ}$ C, a temperature which many researchers feel approximates a threshold temperature for root growth $(6,20,24)$. Bhar et al., (6) found the growth rate of plum roots increased in April when the soil temperature at a $10 \mathrm{~cm}$ depth had risen to $9^{\circ} \mathrm{C}$. Rogers (24) noted little root growth throughout the winter with active root growth beginning when the soil temperature rose above $7^{\circ} \mathrm{C}$. In general, at a $15 \mathrm{~cm}$ depth, a silt loam soil with a sawdust mulch warms to the threshold temperature in March and April and cools to it again in November and December in RI. When the threshold temperature was reached in the early-spring, the growth rate of white unsuberized roots increased (Fig. 1). Leaf bud swell occurred after this initial increase in rate of root growth (Fig. 2) and, as root growth approached its first peak in June, there was a concomitant rise and peak in shoot 
growth (Fig. 3). This peak occurred approximately 2 weeks after the peak in root growth. Rogers $(23,24)$, working with several bush and tree fruits, found an initial increase in the rate of root growth several weeks before the shoots began their growth. Also, the rate of growth of the roots peaked prior to that of the shoots. Rinman (15) and Bhar et al., (6), working with stone fruit trees, found a similar increase in root growth prior to initial shoot growth. Kinman (15) suggested that root growth was needed for nutrient uptake before leaf and fruit development could occur. Researchers have also shown that root-produced hormones, particularly cytokinins and gibberellins, may promote bud activity in the spring and catalyze shoot growth $(18,26,27)$. Mullins (18) successfully substituted synthetic cytokinins for endogenous cytokinins found in the roots to stimulate flower bud break on grape cuttings (Vitis vinifera L.). Skene (27) found that root exudate of grape vines also contained gibberellin-like compounds which have been implicated in the stimulation of shoot elongation.

A number of researchers have noted an antagonistic relationship between root and shoot growth $(3,12,13)$. However, other researchers have shown that root and shoot growth are positively correlated $(1,2,11)$. Luckwill (16) and Raper et al., (22), have developed models that show that the growth of plants is based not on the ratio of 
roots:shoots, but on the ratio of $\mathrm{N}$ uptake:carbohydrate synthesis. Hatton and Amos (10) and Heinicke (14) provided further evidence to suggest that root growth in young apple trees was greatly reduced by early defoliation. Similarly, Hatton and Amos (10) working with young apple trees, demonstrated that root growth was much reduced by summer removal of lateral shoots.

The peak in the growth rate of white unsuberized roots in blueberry in early-June at the time of bloom and fruit set (Fig. 2) occurred when soil temperatures were $14-18^{\circ} \mathrm{C}$ (Fig. 1). The length of white unsuberized roots declined at temperatures outside this range. This temperature range, which our data suggests is optimum for growth of white unsuberized roots in blueberry, also has been noted to be optimum for growth in other fruit species as well $(20,24)$. Nightingale $(20)$, studying root growth of apples and peaches in the laboratory and Rogers (24) working with apples in the field, found that active root growth begins at soil temperatures above $7^{\circ} \mathrm{C}$ and is optimum at $14-20^{\circ} \mathrm{C}$. The decline in the length of white unsuberized roots and rate of shoot growth during late-June to early-August also occurred at the time of completion of fruit set and onset of fruit maturation (Fig. 2). The decline continued throughout much of fruit harvest. This relationship between production of fruit and reduced root and shoot growth has been 
documented previously for other fruit crops $(13,17,24)$. The fruit provides a highly competitive sink for carbohydrates and minerals that, once removed, allows for increased growth of the roots and shoots (25). Weller (28) reported that during the off-year of biennially bearing apple trees, a greater number of roots are formed compared to that produced in an on-year.

The latter part of the harvest season corresponded with the initiation and development of flower buds and occurred at about the time of the second rise in the growth rate of white unsuberized roots and shoot growth (Figs. 2 and 3 ). The peak in shoot growth was slightly prior to the peak in root growth. These peaks corresponded with soil temperatures declining to the optimum range of $14-18^{\circ} \mathrm{C}$ (Fig. 1), the same temperature range at which the rate of root growth peaked in early-June. Subsequently, as temperatures decreased, the roots and shoots exhibited a similar decline in growth. Shoot growth ceased in late-October while the growth of white unsuberized roots continued at a minimum rate throughout the remainder of the year, as in other studies $(2,6,9)$.

Results of this study indicate that in mulched, mature highbush blueberry plants the rate of white unsuberized root growth is interrelated with at least 3 factors: soil temperature, shoot growth, and stage of plant development. 
Growth of white unsuberized roots appears limited by soil temperatures outside the range of 14 to $18^{\circ} \mathrm{C}$. Root and shoot growth in blueberries are not antagonistic and follow the same general patterns, with reduced growth during fruit maturation and harvest. 
Literature Cited

1. Atkinson, D. 1972. Seasonal periodicity of black currant root growth and the influence of simulated mechanical harvesting. J. Hort. Sci. 48:165-172.

2. Atkinson, D. 1973. Seasonal changes in the length of white unsuberized root on raspberry plants grown under irrigated conditions. J. Hort. Sci. 48:413-419.

3. Atkinson, D. 1980. The distribution and effectiveness of the root of tree crops. Hort. Rev. 2:424-490.

4. Ball, E. and C.E.T. Mann. 1927. Studies on the root and shoot development of the strawberry. J. Pomol. and Hort. Sci. $6: 87-103$.

5. Batjer, L.P., J.R. Magness, and L.O. Regeimbal. 1939. The effect of root temperature on growth and nitrogen intake of apple trees. Proc. Am. Soc. Hort. Sci. 37:11-18.

6. Bhar, D.S., G.F. Mason, and R.J. Hilton. 1970. In situ observations on plum root growth. J. Amer. Soc. Hort. Sci. $95(2): 237-239$.

7. Gough, R.E., V.G. Shutak, and D.B. Wallace. 1983. Highbush blueberry culture. Rhode Island Coop. Ext. Ser. Bull. 143 (rev.).

8. Gough, R.E. 1980. Root distribution of 'Coville' and 'Lateblue' highbush blueberry under sawdust mulch. J. Amer. Soc. Hort. Sci. $105(4): 576-578$.

9. Harris, G.H. 1926. The activity of apple and filbert roots especially during the winter months. Proc. Am. Soc. Hort. Sci. 23:414-422.

10. Hatton, R.G. and J. Amos. 1927. Experiments upon the removal of lateral growth on young apple trees in summer. The effect on stem and root development. J. Pomol. and Hort. Sci. 6:61-71.

11. Head, G.C. 1966. Estimating seasonal changes in the quantity of white unsuberized root on fruit trees. J. Hort. Sci. 41:197-206.

12. Head, G.C. 1967. Effects of seasonal changes in shoot 
growth on the amount of unsuberized root on apple and plum trees. J. Hort. Sci. 42:169-180.

13. Head, G.C. 1969. The effects of fruiting and defoliation on seasonal trends in new root production on apple trees. J. Hort. Sci. 44:175-181.

14. Heinicke, A.J. 1936. Root growth in young apple trees made shortly before and after defoliation. Proc. Am. Soc. Hort. Sci. 33:164-165.

15. Kinman, C.F. 1932. A preliminary report on root growth studies with some orchard trees. Proc. Am. Soc. Hort. Sci. $24: 220-224$.

16. Luckwill, L.C. 1960. The physiological relationships of root and shoot. Sci. Hort. 14:22-26.

17. Maggs, D.H. 1963. The reduction in growth of apple trees brought about by fruiting. J. Hort. Sci. 38:119-128.

18. Mullins, M.G. 1967. Morphogenetic effects of roots and of some synthetic cytokinins in Vitis vinifera L. J. Exp. Bot. $18: 206-214$.

19. Nielsen, K.F., R.L. Halstead, and A.J. Maclean. 1961. The influence of soil temperature on the growth and mineral composition of corn, bromegrass, and potatoes. Soil Sci. Soc. Amer. Proc. 25:369-372.

20. Nightingale, G.T. 1935. Effects of temperature on growth, anatomy, and metabolism of apple and peach roots. Bot. Gaz. 96:581-637.

21. North, C.P. and A. Wallace. 1955. Soil temperature and citrus. Calif. Agric., Nov., p. 13.

22. Raper, C.D., D.L. Osmond, M. Wann, and W.W. Weeks. 1978. Interdependence of root and shoot activities in determining nitrogen uptake rate of roots. Bot. Gaz. 139: 289-294.

23. Rogers, W.S. 1932. Root studies III. Pear, gooseberry, and black currant root syustems under different soil fertility conditions, with some observations on root stock and scion effect in pears. J. Pomol. and Hort. Sci. $30: 219-227$. 
24. Rogers, W.S. 1939. Root studies VIII. Apple root growth in relation to rootstock, soil, seasonal, and climatic factors. J. Pomol. 17:99-130.

25. Salisbury, F.B. and C.W. Ross. 1978. Plant Physiology (2 ed.). Wadsworth Publishing Co., Inc. Belmont, CA.

26. Skene, R.G.M. and G.H. Kerridge. 1967. Effect of root temperature on cytokinin activity in root exudate of Vitis vinifera L. Plant Physiol. 42:1131-1139.

27. Skene, K.G.M. 1967. Gibberellin-like substances in root exudate of Vitis vinifera. Planta 74:250-262.

28. Weller, F. 1971. A method for studying the distribution of absorbing roots of fruit trees. Exp. Agric. 7:351-361. 
Figure 1. Elongation of white unsuberized roots of highbush blueberry in relation to soil temperature. Vertical lines represent SE. SE < 1 are not plotted. 

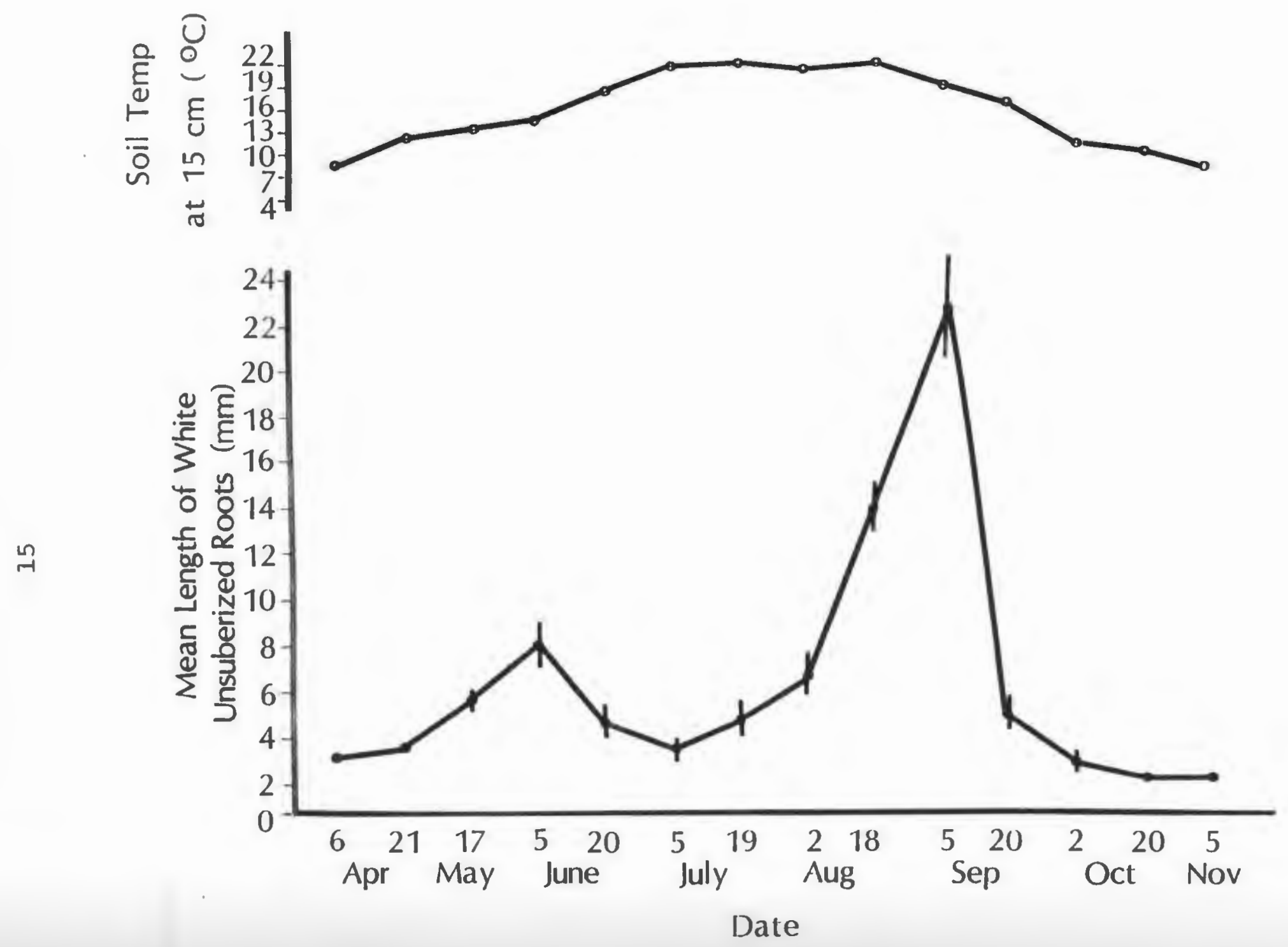
Figure 2. Relationship between mean length of white unsuberized roots and stage in development of highbush blueberry plants.

indicates beginning and ending of stage, indicates peak period of stage. 


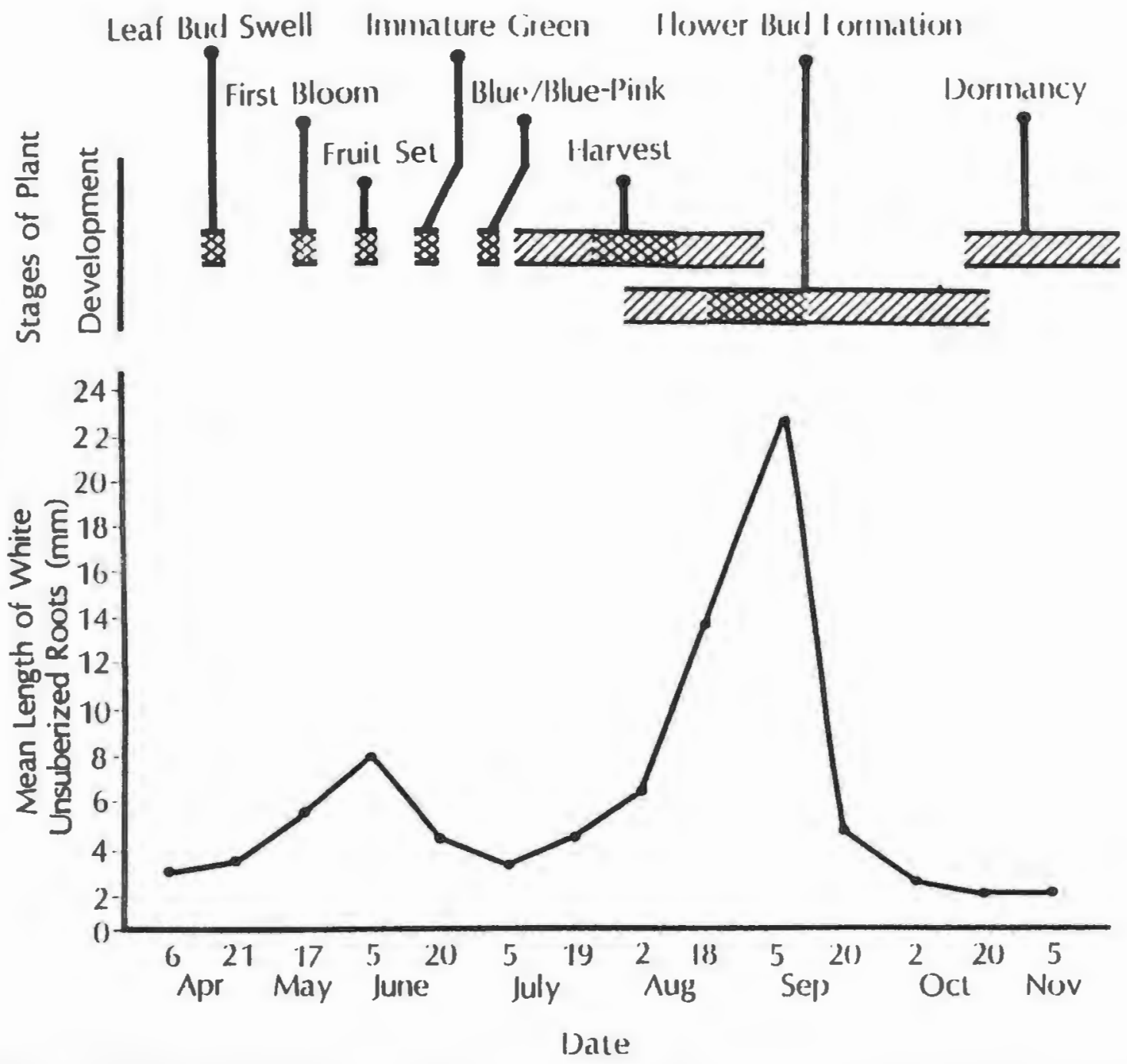


Figure 3. Relationship between the length of white unsuberized roots and shoot growth of highbush blueberry plants. Vertical lines represent SE. $\mathrm{SE}<1$ are not plotted. 
Mean Shoot Growth (mm)

Mean Length of White Unsuberized Roots $(\mathrm{mm})$

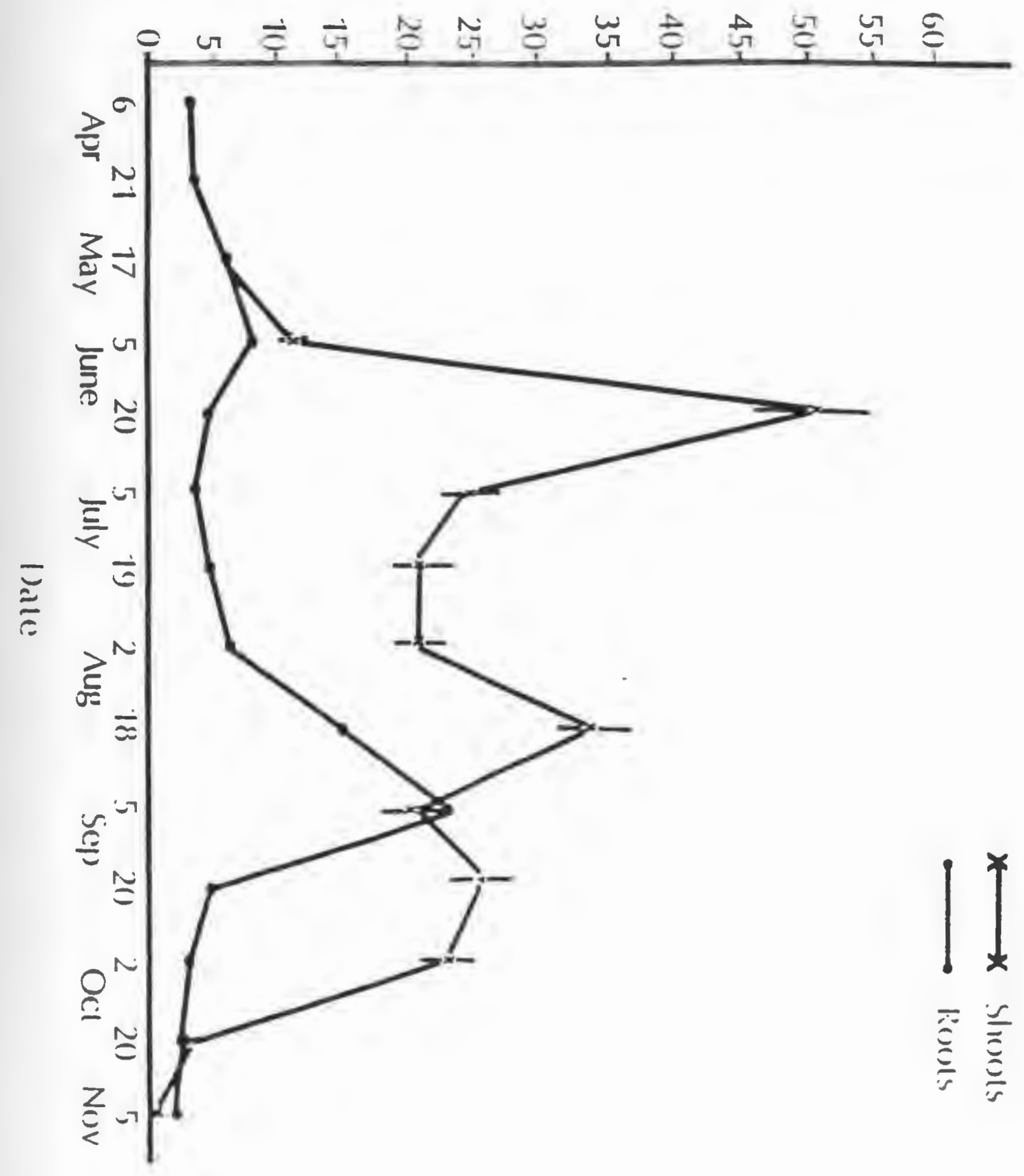


VEGETATIVE GROWTH AND SURVIVAL OF THE HIGHBUSH BLUEBERRY IN RESPONSE TO FLOODING

MANUSCRIPT II 
ABSTRACT

Two-year-old highbush blueberry plants (Vaccinium

corymbosum L. CV. Bluecrop) grown in containers were flooded outdoors beginning in December, April and August to determine the effects of flooding on vegetative growth and survival. Some plants survived more than 26 months of continuous flooding, but vegetative growth was decreased after approximately 4 months of continuous flooding. Plants that were continuously flooded for 4 months and subsequently placed in the field partially recovered. The greatest percentage of plants died when flooding began in April and the lowest percentage when flooding began in December. 
Periodic flooding of forests and croplands is a problem throughout the world and results in huge economic losses $(5,23,30)$. Often areas maintained for the production of horticultural crops are involved. For this reason, the effects of flooding on many horticultural crops such as apples, pears, and stone fruit have been studied extensively $(1,27,31,32)$.

The cultivated blueberry is increasing in popularity and production (9) and researchers have begun to study the effects of flooding on the growth of this plant $(12,20,24,33)$. In one study, rabbiteye (Vaccinium ashei Reade), plants survived, but were severely damaged, after 49-58 days of continuous flooding (11). This species is considered more tolerant to flooding and reduced oxygen levles than highbush blueberry (Vaccinium corymbosumL.) (11,24). Herath and Eaton (20) flooded 1-year-old 'Bluecrop' plants in containers to within 3 inches of the soil surface and noted a decrease in nutrient uptake and plant growth. An important effect of flooding is displacement of oxygen from the soil pores, resulting in oxygen deficiencies and reduced growth $(24,28)$. Even though wild, highbush blueberries are found growing on hummocks in swamps, flooded areas are not recommended for plantations $(17,22)$. This species has a shallow, fibrous root system $(7,15)$ and grows best in moist, well-aerated 
soils $(10,17)$. However, this type of root system may aid the plant in its ability to survive flooding (15), a phenomenon which also has been noted in other species (14), since higher $\mathrm{O}_{2}$ levels, necessary for root growth, frequently occur close to the soil surface in poorly aerated soils (8). Although vegetative growth, including growth of the root, has been studied quite extensively in the highbush blueberry $(13,15,16)$, little is known of the effects of prolonged flooding on the growth and survival of this species. Poorly aerated soils exist in many blueberry plantations in the northeastern U.S. because of periodic flooding. Growers there are concerned about the effects of this condition on the growth of their plants. Therefore, the purpose of this study was to examine the effects of seasonal root zone flooding on vegetative growth, development, and survivability of the cultivated highbush blueberry.

Materials and Methods

This study was conducted using 2-year-old 'Bluecrop' highbush blueberry plants and rooted cuttings of 'Darrow', 'Bluecrop', 'Coville', and 'Bluetta'. The plants were grown in equal volumes of peat : perlite : sand mixture in 7.6 liter plastic containers (2-year-old plants) and 0.5 liter plastic pots (rooted cuttings).

Three, 95 liter, water-filled tubs were sunk into the 
ground. On I December 1983, 16 2-year-old 'Bluecrop' plants and 16 rooted cuttings were submerged into the tubs. The water level was maintained $2.5-5.0 \mathrm{~cm}$ above the media level in the containers. Twelve 2-year-old 'Bluecrop' plants were sunken into the ground to the depth of their containers for controls. After flooding for 4 months, 6 plants were removed from the tubs: the root systems of 3 plants were washed and observed and 3 were sunk into the field with control plants. The remaining plants were maintained under continuous flooding.

A similar, but largely expanded test was conducted in April, August, and December 1984 and in April and August 1985. Flooded plants, including 72, 2-year-old plants and 36 rooted cuttings, were submerged in a black polyethylene-lined, water-filled pit in the field with the water level maintained $2.5-5.0 \mathrm{~cm}$ above the media level in the containers. Following continuous flooding for 4 months in the August and December treatments, 48 plants were removed from the pit, 24 were used for immediate observations and 24 were sunk into the field with the control plants. In the April treatments, several plants died within the first 4 months of treatment, therefore, sample sizes were less than those in the August and December treatments. In the April 1984 treatment, of the 21 plants remaining after the initial 4 months, 13 plants were removed 
from the pit, 5 were used for immediate observations and 8 were sunk into the field with control plants. In the April 1985 treatment, of the 26 plants remaining after the initial 4 months, 16 plants were removed from the pit, 6 were used for immediate observations and 10 were sunk into the field with control plants. Shoot growth was measured on 10 shoots per bush, 10 bushes per treatment. Measurements included: shoot and internode length, and number of nodes. Leaf size, length and width of the third fully expanded leaf (numbered basipetally), were measured in June. Percent of stomata open were determined from leaves of the various treatments at 1000,1200 , and 1400 hours. To examine stomata, the third fully expanded leaf (numbered basipetally) from each of 10 shoots from 10 plants per treatment was used. The abaxial leaf surface was coated with an acrylic laquer and the leaves were removed from the plant. After the lacquer air dried, it was peeled from the leaf surface, forming a negative impression of the stomata. The impression was mounted in glycerin on a microscope slide and examined under a wild M 20 phase contrast light microscope.

Root zone temperatures in the submerged containers and air temperatures within the plant canopy approximately $25 \mathrm{~cm}$ above the media level in the containers were recorded daily. Oxidation-reduction potentials of the media were 
measured using a platinum microelectrode in conjunction with a saturated calomel reference electrode plugged into a Model Altex Phi $30 \mathrm{pH}$ meter (Beckman Instruments Inc., Irvine, (A). The electrodes were inserted approximately $10 \mathrm{~cm}$ into the media, allowed to equilibrate for 1 minute, and a reading in $\mathrm{mV}$ was recorded. Three readings were recorded from each container using 10 containers per treatment. The readings were standardized to a pH of 6.0 at $25^{\circ} \mathrm{C}$. The adjustment was made by adding to or subtracting from the readings $0.059 \mathrm{mV}$ for each $\mathrm{pH}$ unit above or below $\mathrm{pH} 6.0$ (3).

For each of the first 6 weeks following the initiation of the December 1983 flooding, a 2-year-old plant and a rooted cutting were harvested and their roots were washed. Visual observations of root growth and health were made before incubating the root system in a reaction mixture consisting of $0.05 \mathrm{M}$ mono- and di-basic phosphate buffers at pH 7.3 and $0.05 \mathrm{M}$ citric acid. The reaction mixture was boiled and allowed to cool before use. One-tenth percent solution of $2,3,5$ triphenyl tetrazolium chloride (TTC) was then added to the reaction mixture (2), and the washed root systems were incubated for 24 hours at $22^{\circ} \mathrm{C}$ in this solution. The respiratory indicator, TTC, stained the live cells providing an indication of the level of root activity. The staining intensity was recorded by visual determination 
and confirmed by observations of root cell smears with a binocular dissecting scope. The staining intensities recorded include: purplish-red (controls), deep-red, bright-red, pink and colorless (dead) with a lighter color indicating a decrease in root activity.

Following the initial 6 weeks of testing 2-year-old plants and 1-year-old rooted cuttings simultaneously, rooted cuttings only were harvested at approximately bi-weekly intervals throughout the rest of the study. It was found that the 2-year-old plants and 1-year-old rooted cuttings responded similarly to flooding as indicated by the staining intensity. Cuttings were inexpensive and easier to use.

In December 1985, a typical plant from each treatment was selected. The root system was washed and visual observations made prior to air-drying in order to determine relative root-dry weights.

Data were analyzed by analysis of variance and means separated by Duncan's Multiple Range Test. Data recorded as percent was transformed using arc sine prior to analysis. Results and Discussion

Vegetative growth response. Vegetative growth was greatly reduced due to flooding as evidenced by a decrease in shoot and internode length, number of nodes, and leaf size (Tables 1 and 2). The reduction in shoot growth is primarily a result of a decrease in internode elongation 
rather than the number of nodes (Table 1). Stunting of shoot growth in several fruit species as a result of flooding has been well documented $(1,11,19,20)$. After flooding several tree species for 1 month in the autumn, Andersen et al., (1) found a decrease in shoot extension the following spring. Plants flooded for 12 months exhibited an even greater difference in growth than those flooded for only I month. Davies and Wilcox (11) measured regrowth of rabbiteye blueberry shoots after severe pruning and noticed little visible damage with up to 26 days of flooding. However, regrowth of shoots on plants flooded beyond this length of time was impaired. During the summer, the number of shoots formed and the growth rate of the shoots decreased linearly in relation to the number of days the plants were flooded. Our data suggests that there may be a seasonal response in the degree to which shoot grwoth is affected by flooding (Tables 3 and 4 ). This response was greater in plants when flooding was initiated in April as compared to August and December. The seasonal effect of flooding is probably related to the plant's developmental stage at the time flooding is initiated. Heinicke (19) flooded apple trees at various times of the year and found that shoot extension was reduced only when leaves were present. Olien $(26,27)$, also working with apples, found the effect of flooding in the spring was especially severe, and resulted 
in a 338 reduction in shoot extension. In a greenhouse experiment,Olien (26) showed that dormant apple seedlings grew normally after 8 weeks of flooding, whereas actively growing plants were severely stunted. Some studies $(4,6,29)$ indicate that cytokinins manufactured in the roots are transported to the shoots. They are important in maintaining normal growth either by directly affecting shoot growth or influencing the action of other plant hormones that do. Burrows and Carr (6) have shown that the amount of cytokinins transported to the shoots is greatly reduced by waterlogging. The reduction is possibly due to the reduction in rooting volume, decreasing the total amount of cytokinins produced. Railton and Reid (29) reported that the reduction in tomato shoot growth under flooded conditions was normalized by treatment with benzyladenine. Some researchers also found that flooding reduced leaf number, size, and area $(1,4,20)$, as well as promoted early leaf senescence or abscission $(1,4,20)$. Andersen et al., (1) mentioned that reduced leaf size and number indicate a decline in the absorption and transport of water by the flooded roots. The reduced water uptake is a result of xylem disfunction as a result of flooding (1). Jackson and Campbell (2I) have shown that flooding can reduce the water flow through roots. Herath and Eaton (20) using tissue analyses, found a decrease in leaf nutrient elements when 
highbush blueberry plants were flooded to within 3 inches of the soil surface. They proposed that the lack of proper aeration interfered with nutrient uptake by the roots, thus influencing the growth of the shoots.

In addition to a reduction in leaf size, we also found a change in percent of open stomata with flooding (Table 2). Control plants and plants flooded and then planted had a much greater percentage of open stomata than plants continuously flooded. Stomatal closure in response to flooding has been previously documented $(1,11,28)$ and has been looked at as a means of determining a plant's ability to tolerate flooding $(1,11)$. Andersen et al., (1) found that porometry may be used to determine early flood tolerance as long as genetic and environmental factors which influence stomata are considered. The increase in stomatal closure has been linked to a decrease in transpiration, stomatal conductance and carbon assimilation $(1,11,12)$. Davies and Flore (12) found that in rabbiteye and highbush blueberries, flooding decreased stomatal conductance and transpiration within 4 to 5 days. Carbon assimilation decreased within 9 days as a result of a decrease in photosynthesis, stomatal conductance to $\mathrm{CO}_{2}$ and increased respiration (12). Stomatal closure may reduce short-term damage to flooded plants, but it can lead to a reduction in photosynthesis, carbon assimilation and respiration, which 
can ultimately have a significant effect on overall plant growth and survival.

The mean reduction in root dry weight as a result of flooding (control, $156.6 \mathrm{~g}$ vs continuous flooding, $22.1 \mathrm{~g}$ ), is indicative of a decrease in new root growth and decay of existing roots, which others have previously noted $(4,18,19,32)$. The washed root system of the flooded plants appeared black in color while those of the control plants were light-brown. The plants flooded for 4 months and then planted were dark-brown in color. Heinicke (19) noted that there were not apparent effects on root growth when apple trees were flooded in the dormant season. However, root growth was restricted when trees were flooded in the spring and the roots developed a blackened color. Boynton (4) also saw a decrease in the production of new roots in greenhouse-grown apple trees under reduced $\mathrm{O}_{2}$ levels at soil temperatures which normally exist during the spring. Several researchers $(18,19,25)$ have mentioned the seasonal difference in response to flooding and they have attributed it to rising temperatures. Marth and Gardner (25) agreed with Heinicke (19) and Harris (18) stating that greater injury occurred on "hot, sunny" days than on "cool, cloudy" days. Their results are in agreement with more recent work $(1,32)$.

Survival. Flooded highbush blueberry plants survived 
continuous flooding for more than 26 months when submerged beginning in December. However, vegetative growth was minimal (Tables 1-4). There exists a seasonal effect on survival with December-submerged plants surviving better than August-submerged plants and April-submerged plants surviving the worst (Fig. 1). Approximately 30-40z of the plants died within 3 months, when flooding was initiated in April (Fig.1). One-hundred percent of the April 1984 plants were dead within 18 months and although not all the plants were dead, there was a similar trend in 1985. Several other researchers $(11,26,27)$ have noted a decrease in the survival rate during spring flooding and they noted a relationship to temperature. Davies and Wilcox (II) found that rabbiteye blueberry plants which were flooded beginning in the spring, survived as long as 58 days, though the plants were severely damaged. Growth ultimately resumed upon removal of the plants from the flooded conditions. Andersen et al., (1) evaluated several tree fruit species for tolerance to flooding with variable survival rates. Pyrus betulaefolia Bunge. had a $100 \%$ survival rate after 20 months of flooding, whereas 50 of the apple plants (Malus domestics Borkh.) survived 12 months and all of the peach plants (Prunus persical.) died within 1 month. The seasonal effect on flooding may in part be due to rising temperatures. Other researchers have noted an increase 
plant sensitivity to increases in temperature $(8,31,32)$. Rowe and Catlin (32) working with several Prunus species found a decrease in sensitivity to flooding when the root zone temperature was decreased from 27 to $17^{\circ} \mathrm{C}$. The seasonal response of plant survival to flooding corresponded with the staining intensities recorded utilizing TTC. Plants exhibited a purplish-red staining intensity before submergence. However, within a 2-week period of time staining intensity decreased to deep-red (Figs. 2 and 3). As the duration of flooding increased, the staining intensity decreased. It took approximately 1 month more for the December and August-submerged plants to decrease to a pink staining intensity compared to the April-submerged plants in both years (Figs. 2 and 3 ). This reduction in root activity appears to be directly related to the plant's ability to grow and survive in flooded conditions. Childers and white (8) flooded apple trees in glass sided boxes and observed root growth. They found that no new roots formed and all the visible roots already formed appeared dead after 18 days of flooding. Harris (26) noted that a rise in the water table resulted in the cessation of root growth and the eventual death of newly formed roots. The oxidation-reduction potential of the continuously flooded plants decreased rapidly within a few hours and the level was continuously maintained for several months (Fig. 
4). Boynton (4) grew apple trees under controlled soil oxygen levels and found that when the level dropped below $10 \%$ very few rootlets formed and the shoots were injured. Boynton (4) stated that higher oxygen levels are necessary for the production fo new roots than for maintaining the existing root system. Furthermore, a reduction in the production of new roots will limit nutrient and water uptake, ultimately affecting the whole plant. Contrary to earlier beliefs $(7,10,22)$ the cultivated highbush blueberry can survive extended periods of flooding stress providing that it does not occur during the spring, the period of most active growth. However, just as workers with other crops found $(1,11,31)$ the growth and development of the cultivated highbush blueberry are severely limited as a result of flooding. It appears that dormant plants which are flooded are able to somehow adapt prior to the initiation of growth, thus improving their ability to survive. A mechanism by which the highbush blueberry could survive extended lengths of time in flooded conditions has not yet been determined. 


\section{Literature Cited}

1. Andersen, P.C., P.B. Lombard, and M.N. Westwood. 1984. Leaf conductance, growth, and survival of willow and deciduous fruit species under flooded soil conditions. J. Amer. Soc. Hort. Sci. 109:132-138.

2. Berlyn, G.P. and J.P. Miksche. 1976. Botanical microtechnique and cytochemistry. The Iowa state University Press, Ames, Iowa.

3. Black, C.A. 1968. Soil-plant relationships. John Wiley and Sons, New York, NY.

4. Boynton, D. 1940. Soil atmosphere and the production of new rootlets by apple tree root systems. Proc. Am. Soc. Hort. Sci. 37:19-26.

5. Broadfoot, W.M. and H.L. Williston. 1973. Flooding effects in southern forests. J. For. 71:584-587.

6. Burrows, W.J. and D.J. Carr. 1969. Effects of flooding the root system of sunflower plants on the cytokinin content in the xylem sap. Physiol. Plant. 22:1105-1112.

7. Cain, J.C. and G.L. Slate. 1953. Blueberries in the home garden. Cornell Agr. Exp. Sta. Bull. 900.

8. Childers, N.F. and D.G. White. 1942. Influence of submersion of the roots on transpiration, apparent photosynthesis, and respiration of young apple trees. Plant Physiol. 17:603-618.

9. Childers, N.F. 1983. Modern Fruit Science. Horticultural Publications, Gainesville, FL.

10. Coville, F.V. 1910. Experiments in blueberry culture. U.S. Dept. Agr. Pl. Industry Bull. 193.

11. Davies, F.S. and D. Wilcox. 1984. Waterlogging of containerized rabbiteye blueberries in Florida. J. Amer. soc. Hort. Sci. 109:520-524.

12. Davies, F.S. and J.A. Flore. 1986. Gas exchange and flooding stress of highbush and rabbiteye blueberries. J. Amer. Soc. Hort. Sci. In press.

13. Eck, P. 1966. Botany. pp.14-44. In: Eck, P. and N.F. Childers (eds.). Blueberry Culture. Rutgers Univ. Press, New Brunswick, NJ. 
14. Fraser, A.I. and J.B.H. Gardner. 1967. Rooting and stability in Sitka Spruce. U.K. Bull. For. Comm. No. 40.

15. Gough, R.E. 1980. Root distribution of 'Coville' and 'Lateblue' highbush blueberries under sawdust mulch. J. Amer. Soc. Hort. Sci. 105:576-578.

16. Gough, R.E. and V.G. Shutak. 1978. Anatomy and morphology of cultivated highbush blueberry. Rhode Island Coop. Ext. Ser. Bull. 143 (rev.).

17. Gough, R.E., V.G. Shutak, and D.B. Wallace. Highbush blueberry culture. Rhode Island Agr. Exp. Sta. Bull. 423 .

18. Harris, G.H. 1930. The activity of apple and filbert roots especially during the winter months. Proc. Am. soc. Hort. Sci. 26:329-334.

19. Heinicke, A.J. 1932. The effect of submerging the roots of apple trees at different seasons of the year. Proc. Am. Soc. Hort. Sci. 29:205-207.

20. Herath, H.M.E. and G.W. Eaton. 1968. Some effects of water table, $\mathrm{pH}$, and nitrogen fertilization upon growth and nutrient-element content of highbush blueberry plants. Proc. Am. Soc. Hort. Sci. 92:274-283.

21. Jackson, M.B. and D.J. Campbell. 1976. Waterlogging and petiole epinasty in tomato: the role of ethylene and low oxygen. New Phytol. 76:21-29.

22. Render, W.J. and W.T. Brightwell. 1966. Environmental Relationships. pp. 75-93. In: Eck, P. and N.F. Childers (eds.). Blueberry Culture. Rutgers Univ. Press, New Brunswick, NJ.

23. Rennedy, H.E. 1970. Growth of newly planted water tupelo seedlings after flooding and siltation. For. Sci. $16: 250-256$.

24. Korcak, R.F. 1983. Root respiration and soil aeration status of blueberry (Vacciniumsp.). J. of Plant Nutr. $6: 283-289$.

25. Marth, P.C. and F.E. Gardner. 1939. Evaluation of variety peach seedlings stocks with respect to "wet feet" tolerance. Proc. Am. Soc. Hort. Sci. 37:325-337. 
26. Olien, W.C. 1983. Initial research on apple root stocks and water stress. Ann. Rpt. Maine State Pomol. Soc. pp. 23-29.

27. Olien, W.C. 1984. Effects of excessively wet soil on apple. Ann. Rpt. Maine State Pomol. Soc. pp. 19-22.

28. Perira, J.S. and T.T. Kozlowski. 1977. Variations among woody angiosperms in response to flooding. Physiol. Plant. 41:184-192.

29. Railton, I.D. and D.M. Reid. 1973. Effects of benzyladenine on the growth of waterlogged tomato plants. Planta 111:261-266.

30. Reid, D.M. 1977. Crop response to waterlogging. pp. 251287. In: Physiological aspects of crop nutrition and resistance. U.S. Gupta (ed.). Atma Ram, Dehli, India.

31. Rowe, R.N. and D.V. Beardsell. 1973. Waterlogging of fruit trees. Hort. Abstr. 43:533-548.

32. Rowe, R.N. and P.B. Catlin. 1971. Differential sensitivity to waterlogging and cyanogenesis by peach, apricot, and plum roots. J. Amer. Soc. Hort. Sci. $96: 305-308$. 
Table 1. Shoot growth of flooded and control two-year-old contalnerized 'Bluecrop' Dlants (November 1984 and 1985).

\begin{tabular}{|c|c|c|c|}
\hline Areatment ${ }^{2}$ & $\begin{array}{c}\text { Shoot length } \\
(\mathrm{cm})\end{array}$ & $\begin{array}{l}\text { Nodes/ } \\
\text { shoot }\end{array}$ & $\begin{array}{l}\text { Internode } \\
\text { length }(\mathrm{cm})\end{array}$ \\
\hline Control & $5.50 \mathrm{a}^{\mathrm{J}}$ & $7.00 \mathrm{a}$ & $0.79 a$ \\
\hline $\begin{array}{l}\text { Flooded/ } \\
\text { planted }\end{array}$ & $3.70 \mathrm{~b}$ & $6.00 \mathrm{~b}$ & $0.62 \mathrm{~b}$ \\
\hline Continuous & $2.30 \mathrm{c}$ & $5.90 \mathrm{~b}$ & $0.38 \mathrm{c}$ \\
\hline
\end{tabular}

Treatments combined over dates, Including: Dec. 1983, Apr. 1984, Aug. 1984, Dec. 1984 and Apr. 1985.

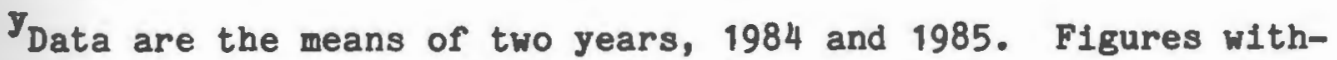
in the same column followed by the same letter are not significantly different at the 5\% level using Duncan's Multiple Range Test. 
Table 2. Size of fully expanded leaves and percent open stomata from flooded and control two-year-old contalnerized 'Bluecrop' plants (17 June, 1985).

\begin{tabular}{|c|c|c|c|}
\hline Ireatment ${ }^{2}$ & $\begin{array}{l}\text { Lear } \\
\text { Length }\end{array}$ & $\begin{array}{l}\text { Size } \\
\text { width }(\mathrm{mm})\end{array}$ & $\begin{array}{l}\text { Stomata } \\
\text { open (8) }\end{array}$ \\
\hline Control & $29.4 \mathrm{a}^{\mathrm{y}}$ & $15.0 \mathrm{a}$ & $85.0 \mathrm{a}$ \\
\hline $\begin{array}{l}\text { Flooded/ } \\
\text { planted }\end{array}$ & $24.1 \mathrm{~b}$ & $11.4 \mathrm{~b}$ & $85.0 \mathrm{a}$ \\
\hline sontinuous & $15.9 c$ & $10.5 \mathrm{~b}$ & $36.5 \mathrm{~b}$ \\
\hline
\end{tabular}

"Treatments combined over dates, including: Dec. 1983, Apr. 1984, Aug. 1984, Dec. 1984, Apr. 1985.

$y_{\text {Figures within the same column followed by the same letter }}$ are not significantly different at the $5 \%$ level using Duncan's Multiple Range Test. 
Table 3. Shoot growth of (looded and control two-year-old contalnerized 'Blueorop' plants as affected by treatment date (Nov, 1984 and 1985).

\begin{tabular}{|c|c|c|c|c|c|c|c|c|c|}
\hline \multirow[b]{3}{*}{$\begin{array}{c}\text { Treatment } \\
\text { date }\end{array}$} & \multirow{2}{*}{\multicolumn{3}{|c|}{ Contreol }} & \multirow{2}{*}{\multicolumn{3}{|c|}{ Ireatment }} & \multirow{2}{*}{\multicolumn{3}{|c|}{ Contsimpus clooding }} \\
\hline & & & & & & & & & \\
\hline & $\begin{array}{c}\text { Shoot } \\
\text { length } \\
\text { (an) }\end{array}$ & $\begin{array}{l}\text { Nodes/ } \\
\text { shoot. }\end{array}$ & $\begin{array}{l}\text { Internode } \\
\text { length } \\
\text { (om) }\end{array}$ & $\begin{array}{l}\text { Shoot } \\
\text { length } \\
\text { (on) }\end{array}$ & $\begin{array}{l}\text { Modes/ } \\
\text { shoot }\end{array}$ & $\begin{array}{l}\text { Internode } \\
\text { length } \\
\text { (am) }\end{array}$ & $\begin{array}{l}\text { Shoot } \\
\text { length } \\
\text { (am) }\end{array}$ & $\begin{array}{l}\text { Nodes/ } \\
\text { shoot }\end{array}$ & $\begin{array}{l}\text { Internode } \\
\text { length } \\
(\mathrm{om})\end{array}$ \\
\hline Dec. $1983^{z}$ & $5.10 d^{x}$ & $5.6 d$ & $0.91 \mathrm{a}$ & $4.0 c$ & $6.4 \mathrm{a}$ & $0.62 c$ & $2.5 b$ & $5.9 b$ & $0.42 b$ \\
\hline Apr. $1984^{2}$ & $6.2 b c$ & $8.0 a$ & $0.79 b$ & $2.8 d$ & $4.7 \mathrm{~b}$ & $0.60 c$ & $1.5 c^{y}$ & $2.1 d^{J}$ & $0.35 b^{y}$ \\
\hline Aug. $1984^{2}$ & $5.6 c$ & $7.5 a b$ & $0.76 b$ & $5.0 b$ & $6.7 a$ & $0.75 b$ & $2.3 a$ & $6.4 \mathrm{ab}$ & $0.36 b$ \\
\hline Dec. $1984^{y}$ & 6.46 & 6.40 & $0.93 a$ & $5.7 a$ & $6.3 a$ & $0.91 a$ & $3.8 \mathrm{a}$ & $6.6 \mathrm{a}$ & $0.57 \mathrm{a}$ \\
\hline Apr. $1985^{y}$ & $6.1 \mathrm{bc}$ & $6.7 \mathrm{bc}$ & $0.91 \mathrm{a}$ & $4.2 c$ & $5.3 b$ & $0.79 b$ & $1.1 \mathrm{c}$ & 5.10 & $0.22 c$ \\
\hline Auce $1985^{y}$ & $7.1 \mathrm{a}$ & 7.36 & $0.98 a$ & $4.9 \mathrm{~h}$ & 6.20 & $0.79 \mathrm{~b}$ & $3.8 a$ & $6.6 n$ & $0.56 a$ \\
\hline
\end{tabular}

Data are the means of two years, 1984 and 1985.

Yata are the means of one year, 1985.

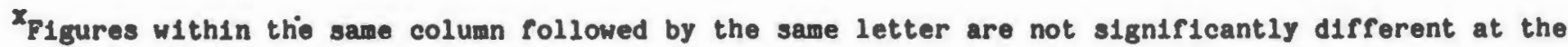
5\% level using Duncan's Multiple Range Test. 
Table 4. Size of fully expanded leaves and percent open stomata from slooded and control two-year-old containerized 'Bluecrop' plants (17 June, 1985).

\begin{tabular}{|c|c|c|c|c|c|c|c|c|c|}
\hline \multirow[b]{3}{*}{$\begin{array}{c}\text { Treatment } \\
\text { datie }\end{array}$} & \multirow{2}{*}{\multicolumn{3}{|c|}{ Contrcol }} & \multicolumn{5}{|c|}{ Ireatment } & \\
\hline & & & & Eleor & ed/olan & ed & ont1nues & Cloodt & \\
\hline & $\frac{\text { Leaf } s}{\text { length }}$ & $\frac{e(\mathrm{~mm})}{\mathrm{N} d \mathrm{dth}}$ & $\begin{array}{l}\text { Stomata } \\
\text { spen (5) }\end{array}$ & heac s & $\frac{e^{2}(\mathrm{~mm})}{\mathrm{vidth}}$ & $\begin{array}{l}\text { Stomata } \\
\text { open (9) }\end{array}$ & lears s & $\frac{(m m)}{n 1 d t h}$ & Stomata \\
\hline Dec. 1983 & $29.8 b^{2}$ & $15.0 \mathrm{ab}$ & $85.0 a$ & $22.0 \mathrm{~b}$ & $11.5 b$ & $79.5 a$ & $16.6 \mathrm{c}$ & $10.3 b$ & $42.0 \mathrm{a}$ \\
\hline Apr. 1984 & $26.4 b c$ & $13.0 \mathrm{~b}$ & $78.0 a$ & $23.0 \mathrm{~b}$ & $11.8 \mathrm{~b}$ & $88.0 a$ & $12.5 d$ & 7.90 & $32.5 a$ \\
\hline Aug. 1984 & $34.0 \mathrm{a}$ & $17.1 a$ & 86.08 & $21.6 b$ & $9.3 c$ & $86.5 a$ & $22.3 b$ & $11.2 b$ & $35.5 a$ \\
\hline Dec. 1984 & $31.4 \mathrm{ab}$ & $16.6 \mathrm{a}$ & $87.5 a$ & $29.8 \mathrm{a}$ & $13.9 a$ & $85.0 a$ & $27.7 \mathrm{a}$ & $14.3 a$ & $37.5 a$ \\
\hline Apc. 1985 & 26.20 & $13.0 \mathrm{~b}$ & $88.5 a$ & $-y$ & $-y$ & $-^{y}$ & 18.20 & $8.9 \mathrm{bo}$ & $35.0 c$ \\
\hline
\end{tabular}

Figures within the same column followed by the same letter are not significantly different at the 58 level using Duncan's Multiple Range Test.

Yreatment did not exist at time of measurement. 
Figure 1. Number of dead two-year-old containerized 'Bluecrop' plants over time as affected by initial date of flooding. 


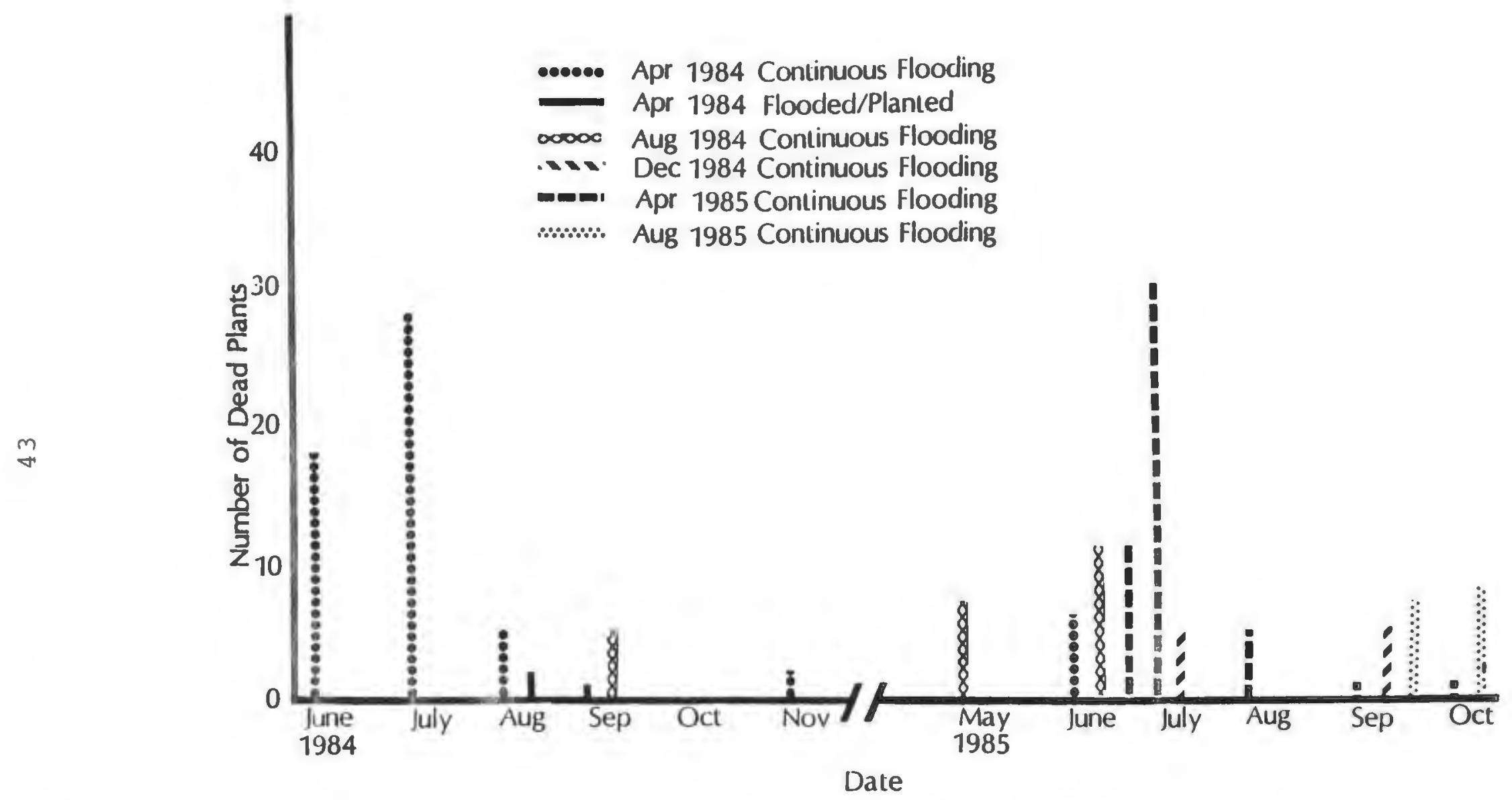


Figure 2. Temperature of the media water and air in the plant canopy in relation to the intensity of $2,3,5$ triphenyl tetrazolium chloride stain (TTC) in roots from flooded one-year-old and two-yearold containerized blueberry plants (1983-1984). 


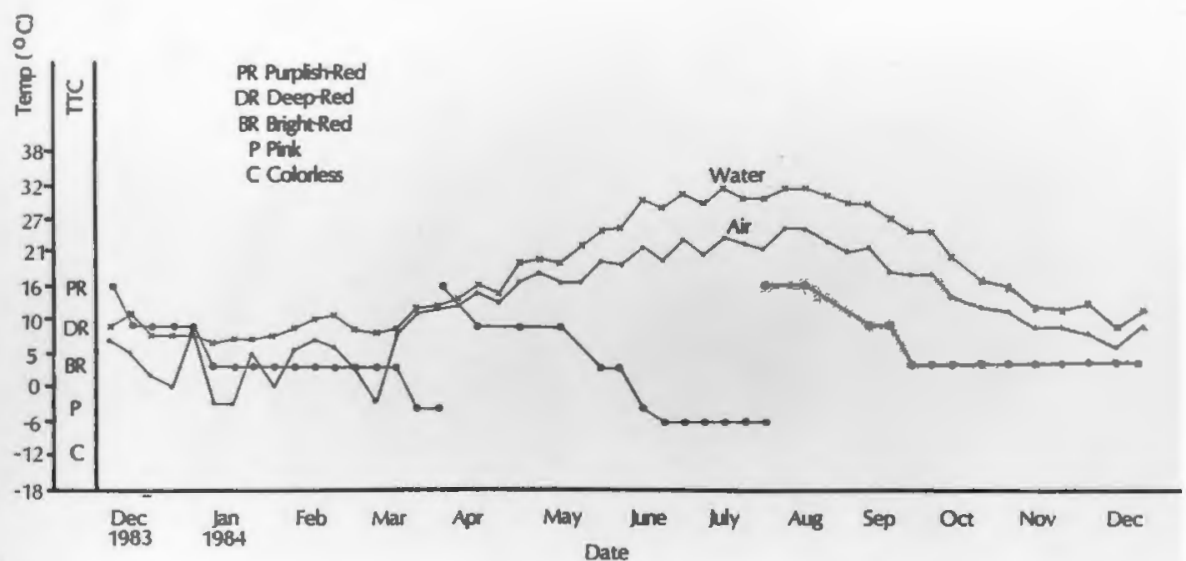


Figure 3. Temperature of the media water and air in the plant canopy in relation to the intensity of 2,3,5 triphenyl tetrazolium chloride stain (TTC) in roots from flooded one-year-old and two-yearold containerized blueberry plants (1984-1985). 


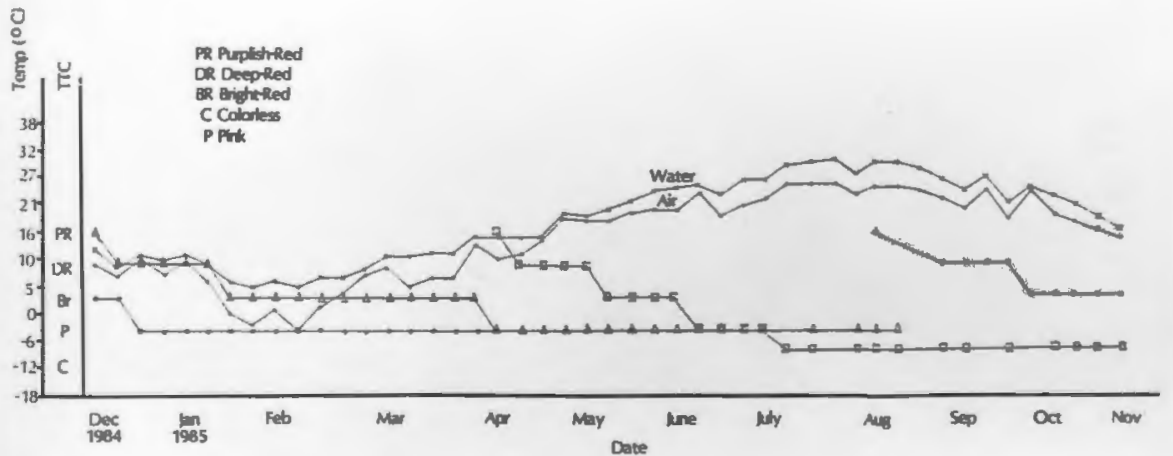


Figure 4. Oxidation-reduction potential of the media from flooded and control two-year-old containerized 'Bluecrop' plants. 
49

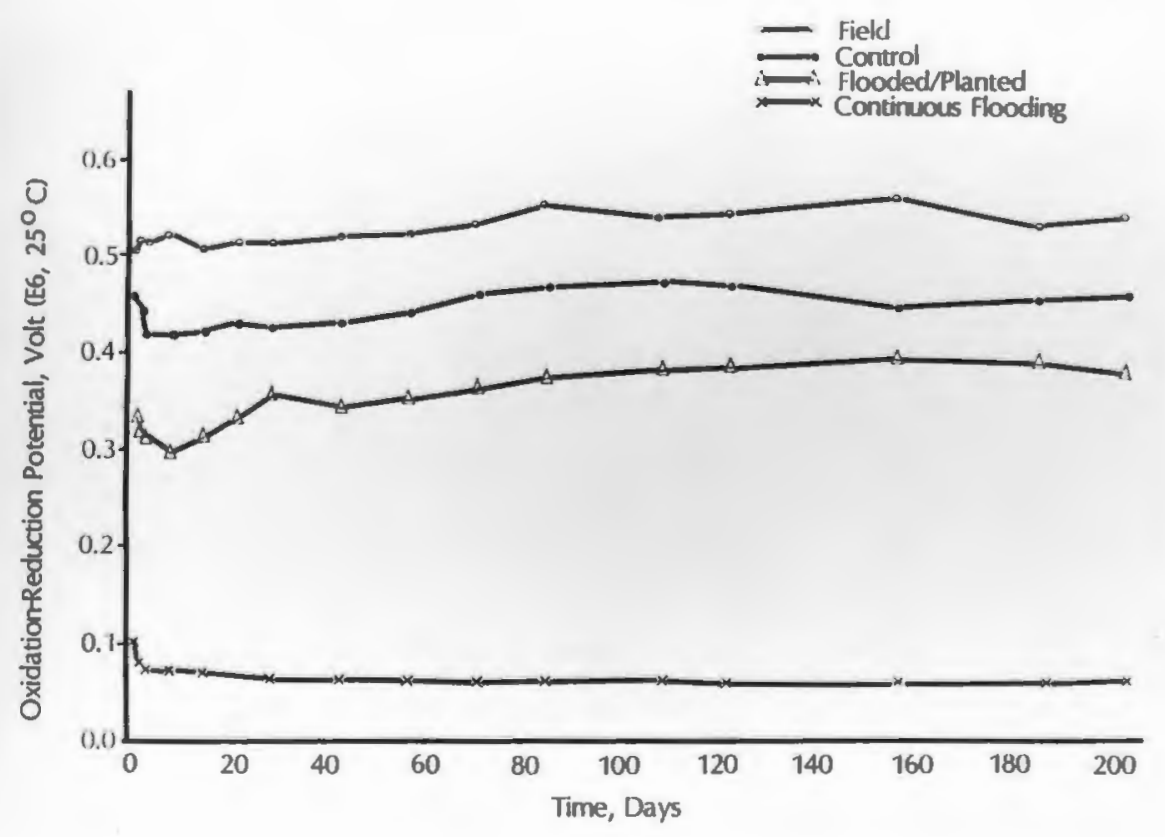


REPRODUCTIVE GROWTH RESPONSE OF THE HIGHBUSH BLUEBERRY TO FLOODING

MANUSCRIPT III 
ABSTRACT

Two-year-old container-grown highbush blueberry plants (Vacciniumcorymbosum L. cv. Bluecrop) were flooded outdoors, beginning in December, April and August, to determine the effects of flooding on reproductive growth. Flooded plants had 61-778 fewer inflorescence buds and 55-66\% fewer flowers per inflorescence bud than non-flooded plants. Anthesis was delayed by almost one week in flooded plants. Fruit set was decreased by 458 and fruit abscision increased with flooding. Weight, size, and soluble solids of fruit from flooded plants were significantly reduced. 
Fruit species vary considerably in their ability to survive extended periods of time in flooded soil $(2,4,5,14)$. Andersen (2) working with several tree fruit species, found that quince (Cydonia oblonga Mill.) and pear (Pyrus spp.) were the most tolerant to flooding, followed by apple (Malus domestica Borkh.) and peach (Prunus persica L.). Davies and Wilcox (5) flooded container-grown rabbiteye blueberry plants (Vaccinium ashei Reade.) and found that their ability to survive was similar to apple (2). Flooding has been found to affect a number of growth processes $(5,8,14)$, and, although vegetative and reproductive growth are interrelated, much of the previous research has been concerned with only the vegetative response, particularly in blueberry $(5,6,8,9)$.

Flooding exists in many blueberry plantations in the northeastern U.S., creating concern among growers about how this condition affects the growth and production of their bushes. The prupose of this study was to examine the effects of seasonal root zone flooding on reproductive growth of the cultivated highbush blueberry.

This study was conducted using 2-year-old 'Bluecrop' plants and rooted cuttings of 'Darrow', 'Bluecrop', 'Coville', and 'Bluetta'. The plants were grown in equal volumes of a peat : perlite : sand mixture in 7.6 liter plastic containers (2-year-old plants) and 0.5 liter plastic 
pots (rooted cuttings).

Three, 95 liter, water-filled tubs were sunk into the ground. On 1 December 1983, 16 2-year-old 'Bluecrop' plants and 16 rooted cuttings were submerged into the tubs. The water level was maintained $2.5-5.0 \mathrm{~cm}$ above the media level in the containers. Twelve 2-year-old 'Bluecrop' plants were sunken into the ground to the depth of their containers for controls. After flooding for 4 months, 6 plants were removed from the tubs; the root systems of 3 plants were washed and observed and 3 were sunk into the field with control plants. The remaining plants were maintained under continuous flooding. A similar, but largely expanded test was conducted in April, August, and December 1984 and in April and August 1985. Flooded plants, including 72 , 2-year-old plants and 36 rooted cuttings, were submerged in a black polyethylene-lined, water-filled pit in the field with the water level maintained $2.5-5.0 \mathrm{~cm}$ above the media level in the containers. Following continuous flooding for 4 months in the August and December treatments, 48 plants were removed from the pit, 24 were used for immediate observations and 24 were sunk into the field with control plants. In the April treatments, several plants died within the first 4 months of treatment, therefore, sample sizes were less than those in the August and December treatments. In the April 1984 
treatment, of the 21 plants remaining after the initial 4 months, 13 plants were removed from the pit, 5 were used for immediate observations and 8 were sunken into the field with control plants. In the April 1985 treatment, of the 26 plants remaining after the initial 4 months, 16 plants were removed from the pit, 6 were used for immediate observations and 10 were sunken into the field with control plants. Inflorescence bud number was determined in November. From this point on "inflorescence bud" will be referred to as flower bud. Length and width of flower buds were measured in the early spring while buds were dormant. Just prior to full bloom, the number of flowers produced per bud were counted. Flower size (length and width) was measured during full bloom. Starting at anthesis, plants were monitored to record date of full bloom, which was considered to occur when approximately 508 of the corollas had dropped. Following full bloom, the number of fruit set was counted and the number of fruit that abscised was determined weekly. Fruit was harvested at the blue-ripe stage and 10 berries per treatment were weighed to determine mean berry weight. Also, fruit size was measured and soluble solids determined at harvest with a hand refractometer Model 10423 (American Optical Co., Keene, NH).

Data were analyzed by analysis of variance and means separated by Duncan's Multiple Range Test. Data recorded 
as percent was transformed using arc sine prior to analysis. Fruiting potential, as determined by the number of flower buds per shoot, number of flowers per bud, percent fruit set and berry weight, was significantly reduced in flooded plants (Tables 1-4). However, when plants were flooded for 4 months and then placed in the field, they were usually able to partially recover (Table 2). Crane and Davies (4) found flower bud development in rabbiteye blueberry declined approximately $50 \%$ when plants were flooded for 15 days or more during the summer. This is similar to our results (Table 2) for the number of flower buds formed per shoot, although we observed a reduction in the range of 80-90\% during the summer. The greatest decrease in flower bud production occurred in the April 1984 and 1985 continuously flooded plants (Table 2). This seasonal effect on growth agrees with previous findings for vegetative growth (1). We saw a similar trend for the number of flowers produced per bud, with significantly fewer from flooded plants (Table 1). Some of the decrease in the number of flowers produced per bud is reflected in the decrease in size of flower buds from flooded plants (Table 1). Anthesis was delayed by almost 1 week and the flower size was reduced in flooded plants (Table 1). This may relate to the decline in absorption and transport of water which could lead to the delay in the expansion of flower 
buds and reduction in flower size as Andersen et al.,

mentioned in regards to leaf growth and expansion. Also, a decrease in root growth under flooding (I) could result in a decrease in nutrient uptake and hormone production (cytokinins, gibberellins) reducing the amounts translocated to the aerial parts of the plant. Since researchers have shown that cytokinins and gibberellins promote bud activity in the spring and stimulate growth $(11,15,16)$, such a decrease could substantially interfere with reproductive activity. Indeed, Heinicke (7) noted that the flowers are the first organs to suffer under flooding stress and their abscission occurs quite often before the shoots are affected. The fruiting potential was further reduced by a greater than 458 reduction in initial fruit set in flooded plants (Table 3). Furthermore, much of the fruit that did set initially in flooded plants abscised prior to harvest (Table 3). MacDaniels and Heinicke (10) associated poor fruit set in apple orchards with a high water table. Crane and Davies (4) found fruit set in rabbiteye blueberry declined to $60 \%$ after 35 days of flooding. The mean berry weight from flooded plants was significantly less, indicating a reduction in yield (Table 4). Several researchers $(3,4,12,13)$ have noted substantial decreases in fruit yields, particularly from submerged apple trees. Olien (12) found fruit yield was reduced by 348 with spring 
flooding (April-June), but there was not effect with summer (July-August) and fall (September-October) flooding. Crane and Davies (4) found a decrease of up to $76 \%$ in fruit yields as a result of flooding for 35 days. In addition to a decrease in fruit set and weight, and an increase in fruit abscision, we noted a decrease in fruit quality. Two determinants of blueberry fruit quality, size and soluble solids, were significantly decreased with flooding (Table 4). Childers et al., (3) also noted a decrease in fruit quality in addition to decreased yields. He reported that fruit from apple trees flooded for 5 weeks during the spring were poor in color, and exhibited a high incidence of cracking.

This research demonstrates that flooding affects reproductive growth and vegetative growth of the cultivated highbush blueberry in similar ways. Blueberry growers can expect a decrease in fruiting potential, production, and quality from bushes grown in flooded areas and should consider this prior to planting in low-lying or flood-prone fields. 


\section{Literature cited}

1. Abbott, John D. and R.E. Gough. 1986. Vegetative growth and survival of the highbush blueberry in response to flooding. J. Amer. Soc. Hort. Sci. In review.

2. Andersen, P.C., P.B. Lombard, and M.N. Westwood. 1984. Leaf conductance, growth, and survival of willow and deciduous fruit tree species under flooded soil conditions. J. Amer. Soc. Hort. Sci. 109:132-138.

3. Childers, N.F., D.G. White, and H.W. Ford. 1943. Effect of ground water table on apparent photosynthesis and growth of apple trees. Proc. Am. Soc. Hort. Sci. $42: 59-60$.

4. Crane, J.H. and F.S. Davies. 1985. Effects of flooding duration and season on rabbiteye blueberry growth and yield. Hortscience 20:529 (Abstr.).

5. Davies, F.S. and D. Wilcox. 1984. Waterlogging of containerized rabbiteye blueberries in Florida. J. Amer. soc. Hort. Sci. 109:520-524.

6. Davies, F.S. and J.A. Flore. 1986. Gas exchange and flooding stress of highbush and rabbiteye blueberries. J. Amer. Soc. Hort. Sci. In press.

7. Heinicke, A.J. 1932. The effect of submerging the roots of apple trees at different seasons of the year. Proc. Am. Soc. Hort. Sci. 29:205-207.

8. Herath, H.M.E. and G.W. Eaton. 1968. Some effects of water table, $\mathrm{pH}$, and nitrogen fertilization upon growth nutrient-element content of highbush blueberry plants. Proc. Am. Soc. Hort. Sci. 92:274-283.

9. Korcak, R.F. 1983. Root respiration and soil aeration status of blueberry (Vaccinium sp.). J. of Plant Nutr. 6:283-289.

10. MacDaniels, L.H. and A.J. Heinicke. 1929. Pollination and other factors affecting the set of fruit, with special reference to the apple. Cornell Agr. Exp. Sta. Bull. 497.

11. Mullins, M.G. 1967. Morphogenetic effects of roots and some synthetic cytokinins in Vitis vinifera $\mathrm{L}$. J. Exp. Bot. 18:206-214. 
12. Olien, W.C. 1984. Effects of excessively wet soil on apple. Ann. Rpt. Maine State Pomol. Soc. pp. 19-22.

13. Olien, W.C. 1983. Initial research on apple root stocks and water stress. Ann. Rpt. Maine State Pomol. Soc. pp. 23-29.

14. Rowe, R.N. and D.V. Beardsell. 1973. Waterlogging of fruit trees. Hort. Abstr. 43:533-548.

15. Skene, R.G.M. and G.H. Rerridge. 1967. Effect of root temperature on cytokinin activity in root exudate of vitis vinifera L. Plant Physiol. 42:1131-1139.

16. Skene, K.G.M. 1967. Gibberellin-like substances in root exudate of Vitis vinifera L. Planta 74:250-262. 
Table 1. Growth of flower buds and flowers from flooded and control two-year-old containerized 'Bluecrop' plants.

\begin{tabular}{|c|c|c|c|c|c|c|c|}
\hline Ireatmantz & $\begin{array}{l}\text { No. Plower } \\
\text { buds/ahoot. }\end{array}$ & $\begin{array}{l}\text { Flower bud } \\
\text { lenath }(\mathrm{mm})\end{array}$ & $\begin{array}{l}\operatorname{siz} e^{x} \\
\text { vidth }\end{array}$ & $\begin{array}{l}\text { No. flowers/ } \\
\text { bud }\end{array}$ & \multicolumn{2}{|c|}{$\begin{array}{l}\text { Flower size } \\
\text { leneth }(\mathrm{mm}) \text { width }\end{array}$} & $\begin{array}{l}\text { Full bloom } \\
\text { date }\end{array}$ \\
\hline Control & $4.3 a^{\prime \prime}$ & $4.9 a$ & $3.0 \mathrm{a}$ & $4.2 a$ & $4.2 \mathrm{a}$ & $2.2 a$ & $17 \mathrm{May}$ \\
\hline $\begin{array}{l}\text { Flooded/ } \\
\text { planted }\end{array}$ & $1.7 \mathrm{~b}$ & $4.4 \mathrm{~b}$ & $2.5 b$ & $1.9 b$ & $3.9 \mathrm{ab}$ & $2.0 \mathrm{ab}$ & $21 \mathrm{May}$ \\
\hline $\begin{array}{l}\text { Cont Inuous } \\
\text { clondine }\end{array}$ & $1.1 \mathrm{~b}$ & $3.9 c$ & 1.90 & $1.4 \mathrm{~b}$ & $3.7 \mathrm{~b}$ & $1.9 b$ & $23 \mathrm{May}$ \\
\hline
\end{tabular}

Treatments combined over dates including Dec. 1983 and Apr. 1984 for mean and Dec. 1983 Apr. 1985 for 1985 mean.

YData are the means of two years, 1984 and 1985.

Xata are the means of one year, 1985.

Wigures within the same column followed by the same letter are not significantly different at at the $5 \$$ level using Duncan's Multiple Range Test. 
Table 2. Auproductive growtis or flooded and control two-yuar-old oontalnerized 'Blueorop' planta es arfeoted by treatment deto.

\begin{tabular}{|c|c|c|c|c|c|c|c|c|c|c|c|c|}
\hline \multirow[b]{3}{*}{$\begin{array}{c}\text { Treataont } \\
\text { dnthe }\end{array}$} & \multicolumn{8}{|c|}{ Iceatment } & \multirow{2}{*}{\multicolumn{4}{|c|}{ Concilnuous Clopdine }} \\
\hline & \multicolumn{4}{|c|}{ Suatcel } & \multicolumn{4}{|c|}{ Eloodud/ulanted } & & & & \\
\hline & $\begin{array}{c}\text { No. } \\
\text { rlower } \\
\text { buds/shoot. }\end{array}$ & $\begin{array}{c}\text { No. } \\
\text { slower.s/ } \\
\text { bud }\end{array}$ & $\begin{array}{l}\text { Prust } \\
\text { is dam. } \\
\text { (mm) }\end{array}$ & $\begin{array}{l}\text { qualdty } \\
\text { syy } \\
\text { (s) }\end{array}$ & $\begin{array}{c}\text { No. } \\
\text { Plower } \\
\text { budskshoot }\end{array}$ & $\begin{array}{c}\text { No. } \\
\text { cluwers/ } \\
\text { bud }\end{array}$ & $\begin{array}{l}\text { Prust } \\
\text { dian. } \\
(\mathrm{n}-1)\end{array}$ & $\begin{array}{l}\text { aualdty } \\
\text { ss } \\
(1)\end{array}$ & $\begin{array}{l}\text { No. } \\
\text { rlowers } \\
\text { Dudelshogt. }\end{array}$ & $\begin{array}{l}\text { No. } \\
\text { rlowers/ } \\
\text { bud }\end{array}$ & $\begin{array}{l}\text { Eoush } \\
\text { dias. } \\
(-1)\end{array}$ & $\begin{array}{l}\text { under } \\
\text { (5) }\end{array}$ \\
\hline Dec. 2983 & $3.7 d^{x}$ & $4.6 \mathrm{a}$ & $15.9 b$ & $11.5 a$ & $1.5 \mathrm{ab}$ & $4.0 a$ & $10.2 b$ & $8.7 \mathrm{~b}$ & $2.4 \mathrm{a}$ & 3.0 & 9.406 & 8.40 \\
\hline Apr. 1984 & $5.1 \mathrm{ab}$ & $4.0 \mathrm{a}$ & $17.8 \mathrm{a}$ & $11.8 \mathrm{a}$ & 0.50 & 0.00 & $0.0 \mathrm{~d}$ & $0.0 \mathrm{~d}$ & $0.0 d$ & $0.0 d$ & 0.00 & $0.0 \mathrm{~b}$ \\
\hline Aug. 1984 & $4.0 \mathrm{~cd}$ & 4. 1a & $17.9 a$ & 11.92 & 0.800 & $1.8 \mathrm{~b}$ & $10.5 c$ & $9.6 b c$ & 0.50 & $0.3 c$ & $10.2 a$ & 9.30 \\
\hline Dec. 1984 & $5.8 \mathrm{a}$ & $4.5 a$ & $17.7 \mathrm{a}$ & $11.6 \mathrm{a}$ & $2.1 a$ & $1.8 \mathrm{~b}$ & $16.5 \mathrm{a}$ & $11.0 \mathrm{a}$ & $1.5 b$ & 1.10 & 10.2 & $8.9 n$ \\
\hline Apr. 1985 & $4.8 D C$ & $-W$ & $16.6 \mathrm{~b}$ & $12.0 \mathrm{a}$ & $1.0 \mathrm{~b}$ & $-*$ & $14.2 b$ & $10.2 b$ & $0.0 d$ & $-"$ & 8.70 & $8.6 a$ \\
\hline 1ma. 1985 & $3.5 d$ & $-w$ & $-W$ & $=$ & 2.32 & $-w$ & $=$ & -4 & $1.6 \mathrm{~h}$ & - & $=$ & - \\
\hline
\end{tabular}

EData are the mans or 1 year, 1985.

Ysoluble sol1ds.

Figures within the same column followed by the same letter are not signiflcantly different at the 58 lavel using Duncen'a Multiplo Range Test.

"Data not avallable at time of wodsurement. 
Table 3. Initial \% fruit set and \& fruit abscised from control and flooded two-year-old containerized 'Bluecrop' plants.

\begin{tabular}{lcc}
\hline Treatment & $\begin{array}{c}\text { Initial } \\
\text { Sruit set }\end{array}$ & $\begin{array}{c}\text { Total \& fruit } \\
\text { abseised }\end{array}$ \\
Control & $87.4 \mathrm{a}^{\mathrm{y}}$ & $13.4 \mathrm{a}$ \\
$\begin{array}{l}\text { Flooded/ } \\
\text { planted }\end{array}$ & $55.3 \mathrm{~b}$ & $39.3 \mathrm{~b}$ \\
$\begin{array}{l}\text { Continuous } \\
\text { looding }\end{array}$ & $52.2 \mathrm{~b}$ & $69.3 \mathrm{c}$ \\
\hline
\end{tabular}

Treatments combined over treatment dates Including Dec. 1983 - Apr. 1985.

yFigures within the same column followed by the same letter are not significantly different at the $5 \%$ level using Duncan's Multiple Range Test. 
Table 4. Fruit weight, size and soluble solids from flooded and control two-year-old containerized 'Bluecrop' plants.

\begin{tabular}{lccc}
\hline $\begin{array}{l}\text { Welght } \\
\text { reatment }\end{array}$ & $\begin{array}{c}\text { Diameter } \\
(\mathrm{g} / \text { bercy })\end{array}$ & $\begin{array}{c}\text { Soluble Solids } \\
(\mathrm{m})\end{array}$ \\
$\begin{array}{l}1.48 \mathrm{a}^{\mathrm{y}} \\
\text { Control }\end{array}$ & $1.10 \mathrm{~b}$ & $17.20 \mathrm{a}$ & $11.00 \mathrm{a}$ \\
$\begin{array}{l}\text { Flooded } \\
\text { planted }\end{array}$ & $12.90 \mathrm{~b}$ & $9.90 \mathrm{~b}$ \\
$\begin{array}{l}\text { Continuous } \\
\text { clooding }\end{array}$ & $0.78 \mathrm{c}$ & $9.60 \mathrm{c}$ & $8.80 \mathrm{c}$ \\
\hline
\end{tabular}

${ }^{2}$ Data are the means of one year, 1985. Treatments over treatment dates including Dec. 1983 - Apr. 1985.

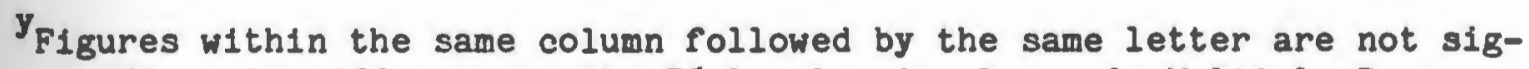
niflcantly different at the $5 \%$ level using Duncan's Multiple Range test. 
ANATOMICAL RESPONSE OF THE HIGHBUSH

BLUEBERRY TO FLOODING

MANUSCRIPT IV 


\section{ABSTRACT}

Roots, stems, leaves, and inflorescence buds were collected from flooded and nonflooded two-year-old container-grown highbush blueberry plants (Vaccinium corymbosum L. cv. Bluecrop). Tissues were fixed in FAA, dehydrated and prepared for light microscopy to determine the effects of the effects of flooding on their anatomy. In addition, roots were also studied with the scanning electron microscope. Examination of root structure revealed expanded epidermal cells, crushed cortical cells and prolifieration and disruption of vascular tissue in flooded plants. The stem structure of flooded plants had disrupted epidermal tissue, condensed outer cortical cells, and large aerenchyma-like mid-cortical cells. The leaf tissue showed an increase in intercellular spaces in the spongy mesophyll complex with a a disrupted palisade layer. There were no apparent differences layer in inflorescence bud anatomy. However, they appeared to be smaller and their formation delayed in flooded plants. 
The cultivated highbush blueberry root system is shallow and fibrous $(6,8,10,17)$ and most roots are concentrated within the drip-line of the bush to a depth of 15-25 cm (10). This shallow rooting depth may allow the plant to better tolerate waterlogged soil conditions $(1,10)$. The ability of shallow rooted plants, such as the blueberry, to survive flooded soil conditions also has been noted in other plant species (9). Survival has been attributed to the higher oxygen levels existing closer to the soil surface (9). Inherently, some plant species can withstand flooding better than others $(3,23,24)$. Characteristics found to increase flood tolerance include: increased development of internal air spaces that allow a greater oxygen supply to the roots $(7,21,26)$, the development of adventitious roots $(7,13,28)$, and metabolic modifications such as decreased ethanol production and alternative energy pathways (14). According to Kramer (18), a rapid reduction in water absorption and increased resistance to its movement may cause stomatal closure to maintain cell turgor. Davies and Flore (5) determined that blueberries adapt to flooded conditions mostly by limiting water loss through stomatal closure, but they felt this may be a short-term flooding response.

Changes in anatomy of roots, stems, and leaves, as a long-term survival mechanism, have been examined in several 
plant species $(7,13,21,26,28)$, but not in blueberry. Our objective in this study was to compare the anatomy of roots, stems, leaves and inflorescence buds from flooded and non-flooded plants of the cultivated highbush blueberry to determine if these structures have been modified by flooding.

\section{Material and Methods}

The study was conducted over a 1 year period using flooded and non-flooded (control) 2-year-old 'Bluecrop' plants, as previously descrived (1). Approximately 100 roots with white tips and 10 stems were collected from plants in each treatment at various intervals from April 1984 through April 1985. The dormant fourth inflorescence bud (numbered basipetally) was collected from each of 5 shoots from each treatment in the early spring. From this point on, "inflorescence bud" will be referred to as flower bud. Leaf samples from the third fully expanded leaf (numbered basipetally) of each of 5 shoots from each treatment were collected from mid-June through leaf abscision (September-October).

Root, stem, leaf, and bud samples were fixed in FAA, dehydrated through an ethanol/t-butanol series and embedded in Paraplust-Plus, according to standard microtechniques (25). Root tissue was cross sectioned approximately 10-25 mm behind the root apex, which Petersen et al., (22), 
described as light-yellow to golden-brown in color. Stem tissue was sectioned approximately 3-5 mm above the fourth flower bud and leaf tissue through the widest portion of the blade. Flower buds were cross-sectioned through their widest portion.

Prepared tissue was sectioned at $10 \mu \mathrm{m}$, stained with Fast Green FCF and mounted on a microscope slide in Permount. Sections were examined with a Wild M 20 Phase Contrast Microscope fitted with an eyepiece micrometer. Photomicrographs of representative sections were taken with a Nikon Optiphot Microscope fitted with a Nikon AFX camera attachment. For SEM studies, the root segments were cut into 1-2 mm segments using a hand-held microtome blade. They were transferred through an ethanol series into 2 changes of 100 othanol. Tissues were then critical point dried (Ted Pella Co., Tustin,CA) using carbon dioxide as the intermediate fluid. Samples were mounted on aluminum stubs with silver paste, coated under vacuum with a gold/palladium $(60 / 40)$ alloy and examined with a Cambridge Stereoscan scanning electron microscope (SEM).

\section{Results and Discussion}

The influence of flooding on root structure is illustrated by representative light and scanning electron microscope micrographs (Figs. 1-9). The overall appearance of the control roots was one of turgidity and relative 
symmetry, while portions of the flooded roots appeared to be collapsed and shriveled (Figs. 1 and 2 ). The surface of the epidermal cells appeared convex and symmetrical in control roots (Fig. 1), while the same cells on the flooded roots appeared concave, supported only by the intersecting cell walls, which themselves appeared to have lost some rigidity (Fig. 2). In cross section, the epidermal cells of the control roots appeared fairly circular, whereas similar cells in the flooded roots were more quadrangular, with surface walls concave. Epidermal cells in flooded roots were about $30 \%$ larger than similar cells in control roots (Figs. 1 and 2 ). Researchers have noted a similar response in other crops such as corn, rice, and sunflower $(7,21,28)$, though such cell expansion occurred in the cortex not the epidermis. Drew et al., (7), found that cortical air spaces are induced by small concentrations of ethylene in zea mays. Kawase's review (16) on this subject discusses the formation of cortical air spaces which can be either lysigenous or schizogenous in origin. Research suggests that these air spaces may provide a pathway for the transport of oxygen from the shoots to the flooded roots (16). Armstrong (4) suggests that the formation of cortical aerenchyma improves oxygen status of the roots by reducing the amount of respiring tissue and by providing a means by which oxygen can diffuse from shoots to roots with 
minimal resistance.

The cortical region of the control roots appeared to be 3-4 cell layers thick (Figs, 1-4). The cells were similar in cross-section appearance to epidermal cells. However, the cortical region in the flooded roots appeared to be crushed, with some cells only about $1 / 3$ the size of cortical cells in control roots. Outer-cortical cells appear to have been crushed in a plane perpendicular to the central root axis, while inner-cortical cells are severely crushed along no particular plane. The cortical region in contrul is about $40 \mu \mathrm{m}$ thick, while that in the flooded roots has been crushed to a thickness of only about $14 \mu \mathrm{m}$.

Crushing and collapse of some regions of the root have been reported by various researchers $(7,12)$. The degeneration of cortical cells may be a result of cell collapse due to membrane damage (7). Horton and Osborne (12) suggested the existence of "target cells" for ethylene. These "target cells" are exposed to elevated concentrations of ethylene which might cause those cells to expand while adjacent cells degenerate largely because of hydrolytic enzymes produced by the expanding "target cells".

In fact, the distorted cortical region in flooded roots may be a result of both collapse of cortical cells and the crushing effect of expanded epidermal cells and stelar proliferation. 
The vascular system of control roots is about $28 \mu \mathrm{m}$ in diameter and intact (Figs. I and 3). That of the flooded roots, however, appears to have proliferated $(48 \mu \mathrm{m}$ diameter) and become crushed and distorted, perhaps impairing its function (Figs. 2 and 4 ). The nature of the vascular elements is indistinguishable.

The stem structure from control and flooded plants is shown in light photomicrographs (Figs. 5 and 6 ). In control and flooded stems there is a cuticular layer covering the surface of a single layer of epidermal cells which are similar in thickness and, while the epidermis in control stems is ordered and symmetrical, that in the flooded stems is not. The outer-cortical region is several cells thick. However, the cells appear smaller, darkly stained, and more condensed in stems of flooded plants. The mid-cortical region of stems from flooded plants has large intercellular spaces surrounded by isodiametric parenchyma cells attached to each other in threadlike constructions. Mahlstede and Watson (19) termed these spaces air ducts and reported seeing them in cortical regions of 1-year-old stem cuttings taken from 4-year-old 'Jersey' plants grown in a peat-bog, the conditions of which may approach those of our continuously flooded plants at certain times of the year. However, because of remnants of membranes surrounding them, they appear to be more like 
aerenchyma than merely large spaces or ducts. There appears to be more of these spaces in stems of flooded plants. In similar findings, Kawase (15), in photomicrographs of stem tissue from flooded sunflower plants, exhibited an enlargement of the cortical layer which leads to aerenchyma development. Just as in the roots, the increase in intercellular spaces in the cortex may provide a pathway of low resistance for the diffusion of oxygen from the shoots to the roots.

There are no apparent differences in structure between stelar regions of flooded and control stems. Tissues in this region appear similar to those in Mahlstede and Watson's description (19).

Light photomicrographs of the leaf structure from control and flooded plants also provided some differences (Figs. 7 and 8 ). The overall structure of the leaves, particularly the control leaves, was similar to that documented by Gough and Shutak (11). When compared to those from flooded plants, the leaves from control plants appeared to have a slightly thicker upper epidermal layer with no measurable difference in cuticle thickness. The single-celled epidermal layer was subtended by 1 or 2 layers of palisade cells. The palisade layer of the leaves from flooded plants appeared disrupted in comparison to leaves of control plants and the cells were about $1 / 2$ as long. 
Beneath the palisade layer is the spongy mesophyll complex which appeared disorganized resulting in an increase in intercellular spaces. The increased spaces in the spongy mesophyll complex and thinner epidermal layer may increase the uptake and movement of oxygen from leaves to stems to roots. As was the case with the upper epidermal layer, the lower epidermis is single celled and appears slightly thicker in leaves from control plants. Mahlstede and Watson (19) stated that plants in moist habitats often possess a thinner cutical and epidermal layer. The alteration in leaf structure may be related to the inhibiting influence of flooding on leaf initiation and expansion (27). The reduction in initiation and expansion ultimately influences number and size of leaves, just as Abbott and Gough (1) documented previously.

There were no apparent differences in flower bud anatomy, though flower buds from flooded plants were smaller than those from control plants, which Abbott and Gough noted previously. The development of flower buds on flooded plants is delayed. This also agrees with previous observations in which anthesis was delayed by almost 1 week in flooded plants (2).

As would be expected, flooding has a disruptive influence on overall plant growth and development. The increase in intercellular spaces in leaves, cortical air 
spaces in shoots, and expansion of root epidermal cells may provide a possible explanation as to why the highbush blueberry is able to survive under continuous flooding for more than 26 months (1). In the case of blueberry, the expanded epidermal cells maybe functioning as aerenchyma in other species. However, there are other factors such as modification in plant metabolism, which should also be studied and could possibly provide important information as to the adaptability of the highbush blueberry to flooding. 


\section{Literature Cited}

1. Abbott, John D. and R.E. Gough. 1986. Vegetative growth and survival of the highbush blueberry in response to flooding. J. Amer. Soc. Hort. Sci. (In review).

2. Abbott, John D. and R.E. Gough. 1986. Reproductive growth response of the highbush blueberry to flooding. HortScience (In review).

3. Andersen, P.C., P.B. Lombard, and M.N. Westwood. 1984. Leaf conductance, growth, and survival of willow and deciduous fruit species under flooded soil conditions. J. Amer. Soc. Hort. Sci. 109(2):132-138.

4. Armstrong, W. 1979. Aeration in higher plants. Adv. Bot. Res. $7: 225-332$.

5. Davies, F.S. and J.A. Flore. 1986. Gas exchange and flooding stress of highbush and rabbiteye blueberries. J. Amer. Soc. Hort. Sci. In press.

6. Doehlert, C.A. 1937. Blueberry tillage problems and a new harrow. J. Agr. Exp. Sta. Bull. 625 .

7. Drew, M.C., M.B. Jackson, and S. Gifford. 1979. Ethylene promoted adventitious rooting and development of cortical air spaces (aerenchyma) in roots may be adaptive responses to flooding in zea mays $\mathrm{L}$. Planta $147: 83-88$.

8. Eck, P. 1966. Botany. pp.14-44. In: Eck, P. and N.F. Childers (eds). Blueberry Culture. Rutgers Univ. Press, New Brunswick, NJ.

9. Fraser, A.I. and I.B.H. Gardner. 1967. Rooting and stability in Sitka Spruce. U.K. Bull. Form. Comm. No. 40 .

10. Gough, R.E. 1980. Root distribution of 'Coville' and 'Lateblue' highbush blueberry under sawdust mulch. J. Amer. Soc. Hort. Sci. 105 (4) 576-578.

11. Gough, R.E. and V.G. Shutak. 1976. Effect of SADH on leaves of cultivated highbush blueberry. Hortscience $11: 514-515$.

12. Horton, R.F. and D.J. Osborne. 1967. Senescence, 
abscision, and cellulase activity in Phaseolus vulgaris. Nature (London) 214:1086-1088.

13. Jackson, W.T. 1955. The role of adventitious roots in recovery of shoots following flooding of the original root system. Am. J. Bot. 42:816-819.

14. Jackson, M.B. and M.C. Drew. 1984. Effects of flooding on herbaceous plants. pp.47-128. In: T.T. Kozlowski (ed). Flooding and Plant Growth. Academic Press, Orlando, FL.

15. Kawase, M. 1974. Role of ethylene in induction of flooding damage in sunflower. Physiol. Plant. 31:29-38.

16. Kawase, M. 1981. Anatomical and morphological adaptation of plants to waterlogging. Hortscience $16: 30-34$.

17. Kender, W.J. and W.T. Brightwell. 1966. Environmental relationships. pp. 75-93. In: Eck, P. and N.F. Childers (eds). Blueberry Culture. Rutgers Univ. Press, New Brunswick, NJ.

18. Kramer, P.J. 1940. Causes of decreased absortion of water by plants in poorly aerated media. Am. J. Bot. $27: 216-220$.

19. Mahlstede, J.P. and D.P Watson. 1952. An anatomical study of root development in stems of Vaccinium corymbosum. Bot. Gaz. 113:279-285.

20. McManmon, H. and R.M.M. Crawford. 1971. A metabolic theory of flooding tolerance. The significance of enzyme distribution and behavior. New Phytol. $70: 299-306$.

21. McPherson, D.C. 1939. Cortical air spaces in the roots of Zea mays L. New Phytol. 38:190-202.

22. Petersen, T.A., W.C. Mueller, and L. Englander. 1980. Anatomy and ultrastructure of Rhododendron root-fungus assosciation. Can. J. Bot. 58:2421-2433.

23. Rowe, R.N. and P.B. Catlin. 1971. Differential sensitivity to waterlogging and cyanogenesis by peach apricot, and plum roots. J. Amer. Soc. Hort. Sci. $96(3): 305-308$. 
24. Rowe, R.N. and D.V. Beardsell. 1973. Waterlogging of fruit trees. Hort. Abstract 43:533-548.

25. Sass, J.E. 1951. Botanical microtechnique. 2 ed. Iowa State College Press, Ames, Iowa.

26. Sifton, H.B. 1945. Air space tissues in plants. Bot. Rev. 11:108-143.

27. Tang, Z.C. and T.T. Kozlowski. 1982. Physiological, morphological, and growth responses of Plantanus occidentalis seedlings to flooding. Plant Soil $66: 243-255$.

28. Wample, R.L. and D.M. Reid. 1975. Effect of aeration on flood induced formation of adventitious roots and other changes in sunflower (Helianthus annuus L.) Planta $127: 263-270$. 
Figure 1. Scanning electron photomicrograph of a cross section of a 'Bluecrop' blueberry root from a control plant. Scale bar $=11 \mu \mathrm{m}$. Epidermis (E); Cortex (C), Endodermis (Ed); Stele (S). 
79

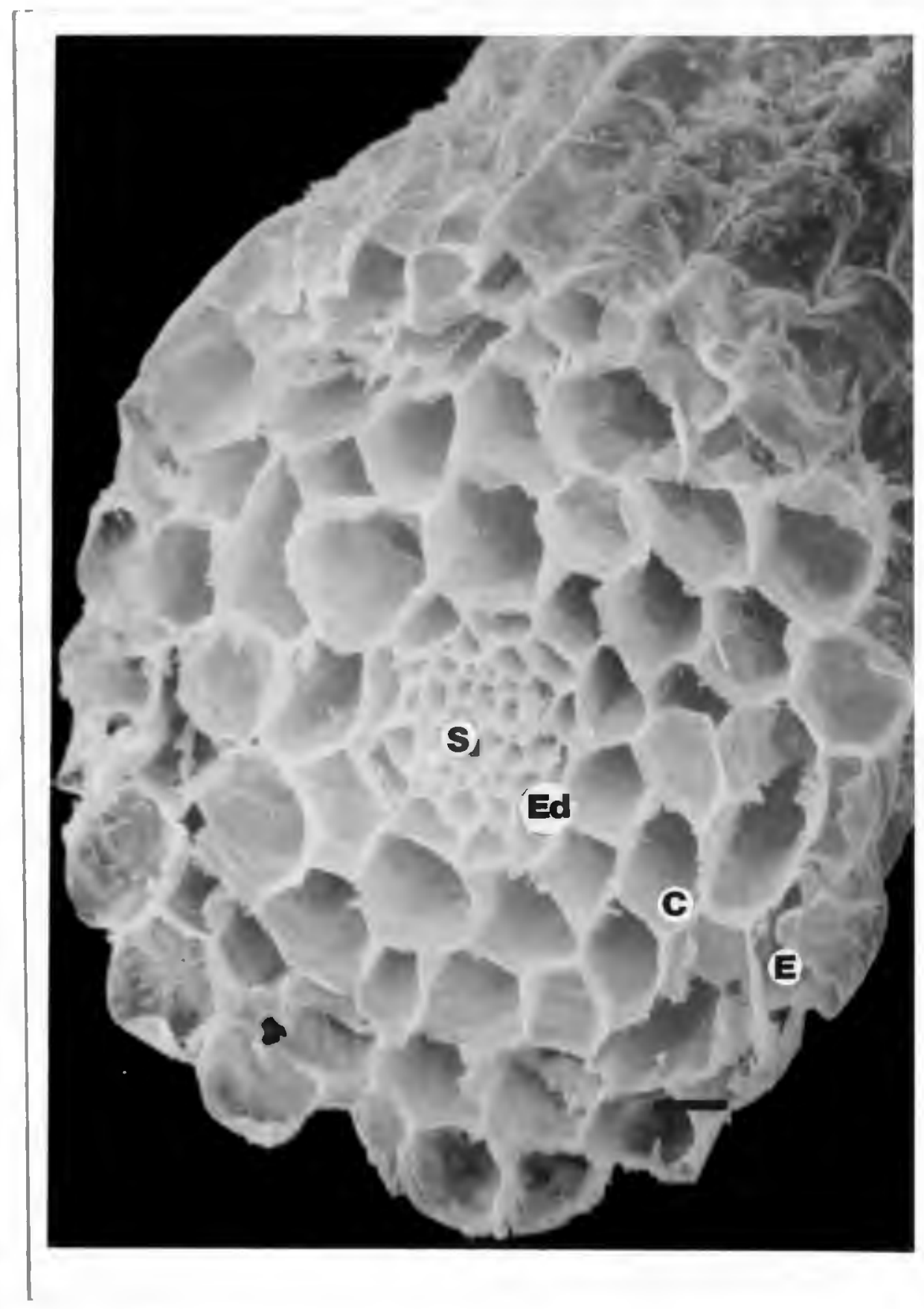


Figure 2. Scanning electron photomicrograph of a cross section of a 'Bluecrop' blueberry root from a flooded plant showing expanded epidermal cells distorted cortex, and proliferated, crushed vascular tissue. Scale bar $=10 \mathrm{~m}$. Epidermis (E); Cortex (C); Stele (S). 


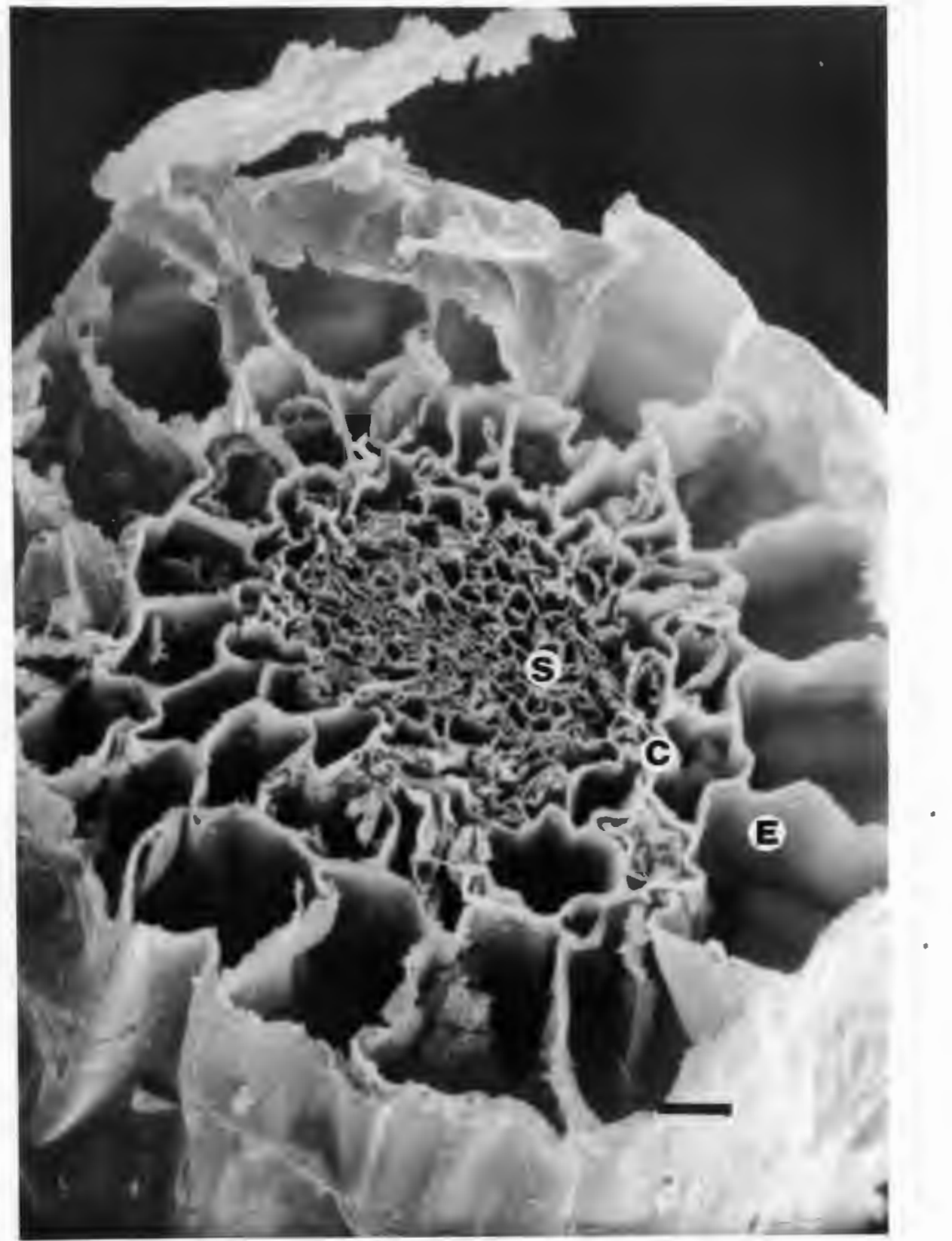


Figure 3. Light micrograph of a cross section of a 'Bluecrop' blueberry root from a control plant Scale bar $=42 \mu \mathrm{m}$. Epidermis (E); Cortex (C): Stele (S); Lateral root (L). 
83

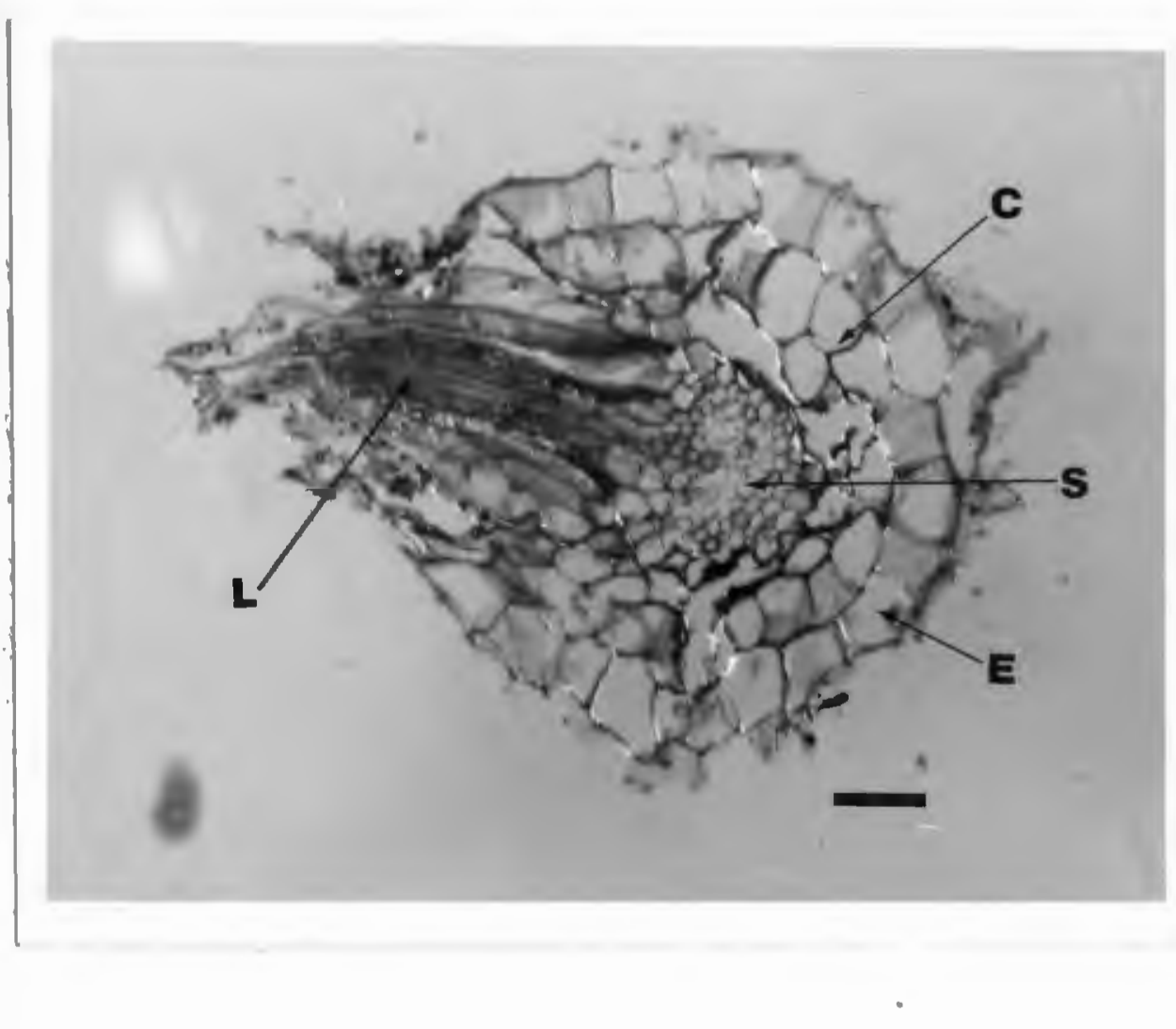


Figure 4. Light micrograph of a cross section of a 'Bluecrop' blueberry root from a flooded plant, showing expanded epidermal cells, crushed cortex, and distorted vascular tissue. Scale bar $=70 \mu \mathrm{m}$. Epidermis $(E)$; Cortex (C); Stele (S): Lateral root (L). 
85

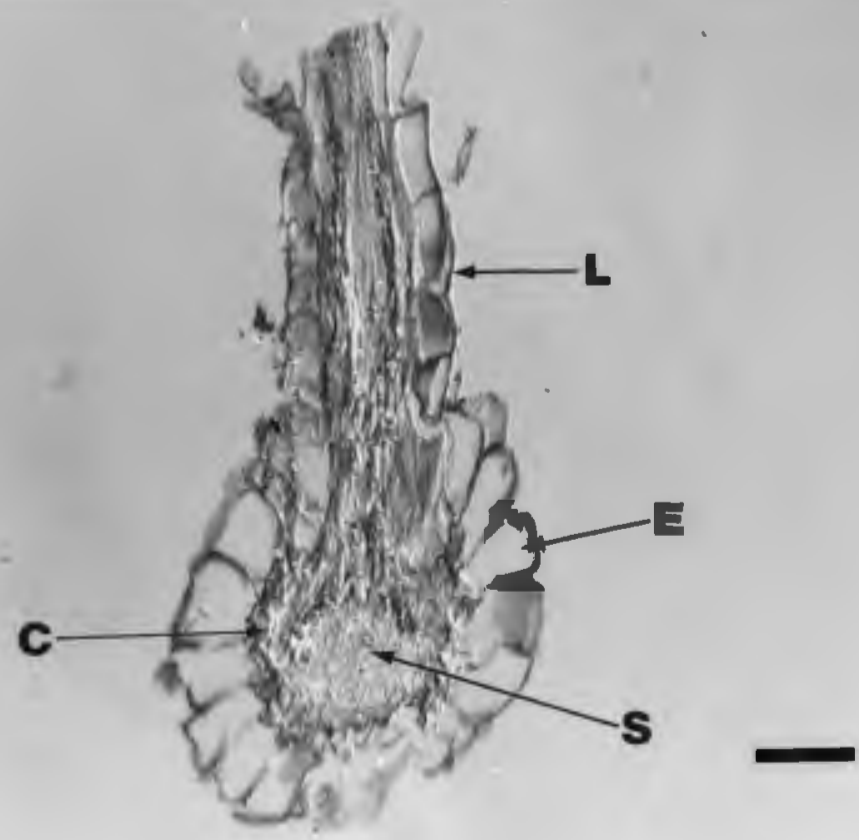


Figure 5. Light micrograph of a cross section of a

'Bluecrop' blueberry stem from a control plant. Scale bar $=65 \mu \mathrm{m}$. Cuticle $(C)$; Epidermis $(E)$; Outer-cortex (0); Mid-Cortex (M); Inter-Cortex (I). 


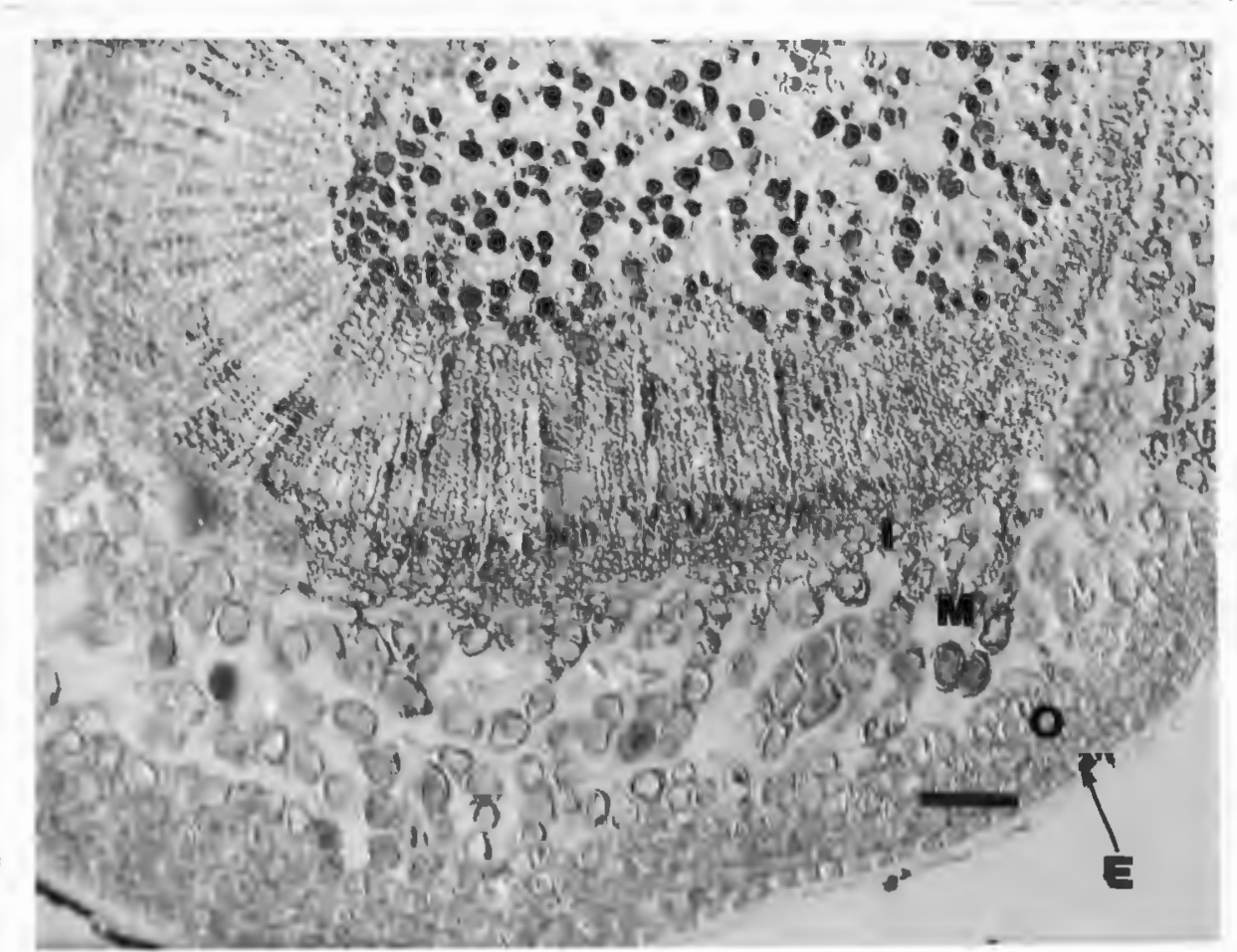


Figure 6. Light micrograph of a cross section of a 'Bluecrop' blueberry stem from a flooded plant showing large cortical air spaces. Scale bar $=69 \mu \mathrm{m}$. cortex (C): Epidermis (E): Outer-cortex (O); Midcortex (M); Inner-cortex (I); Aerenchyma (A). 


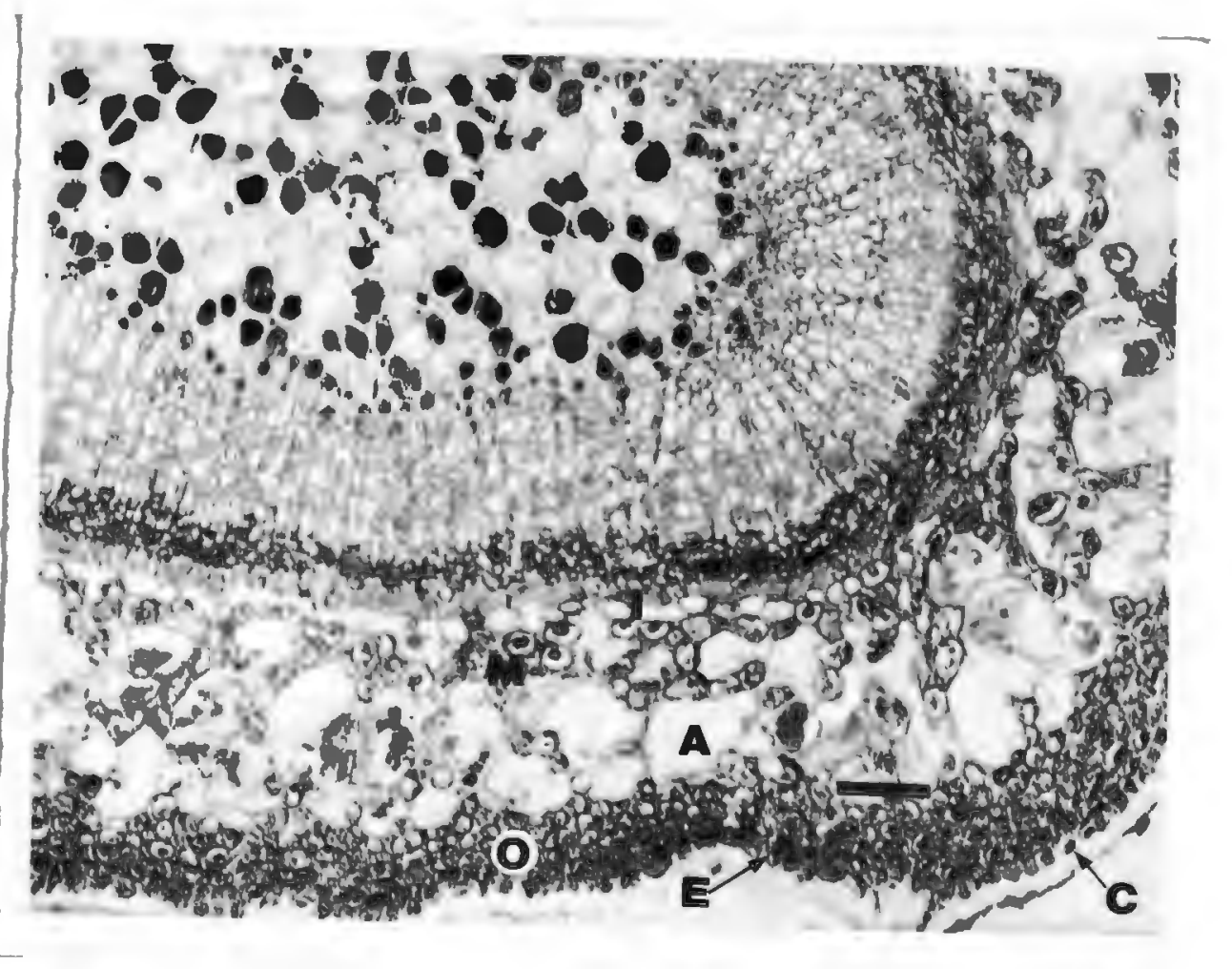


Figure 7. Light micrograph of a cross section of a 'Bluecrop' blueberry leafblade from a control plant. Scale bar $=68 \mathrm{\mu m}$. Cutical (C); Epidermis (E); Vascular tissue (V); Spongy mesophyll Complex (S); Palisade layer (P). 


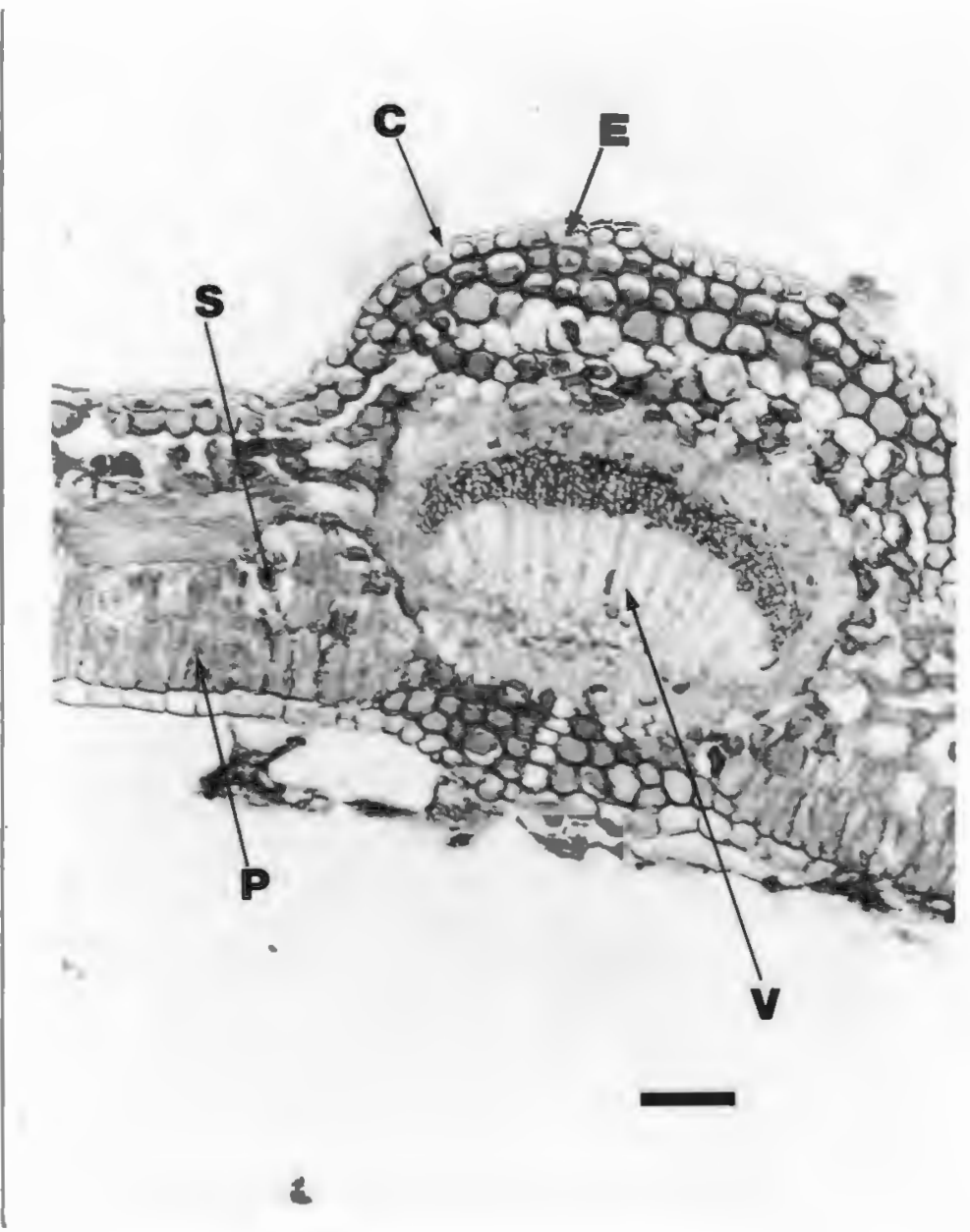


Figure 8. Light micrograph of a cross section of a 'Bluecrop' blueberry leaf blade from a flooded plant showing disrupted palisade layer and increased air spaces in the spongy mesophyll complex. Scale bar $=\mu \mathrm{m}$ Cuticle (C); Epidermis (E); Vascular tissue (V); Spongy mesophyll complex (S): Palisade layer (P). 


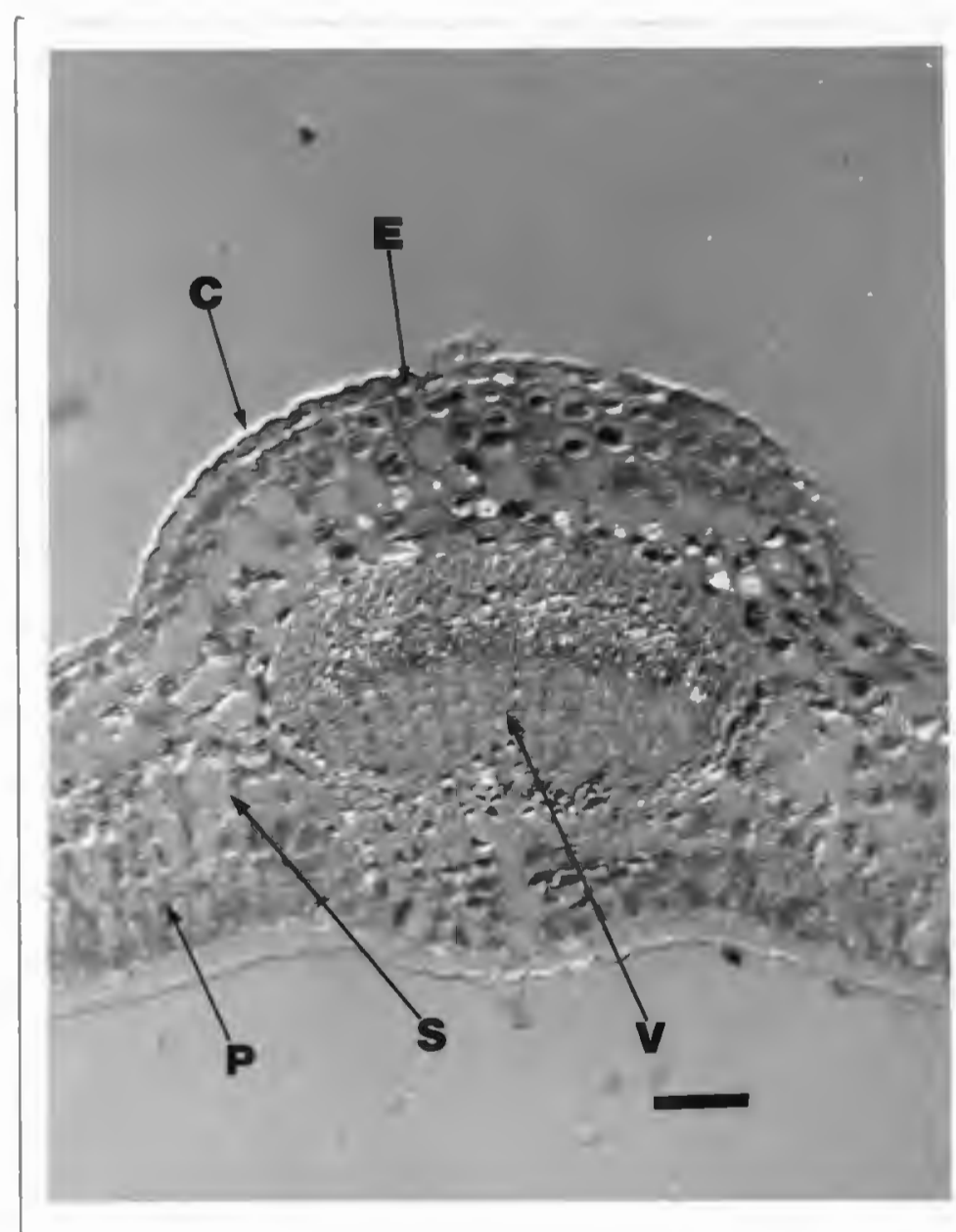


Figure 9. Light micrograph of a cross section of a 'Bluecrop' blueberry flower bud from a control plant. Scale bar $=150 \mu \mathrm{m}$. 


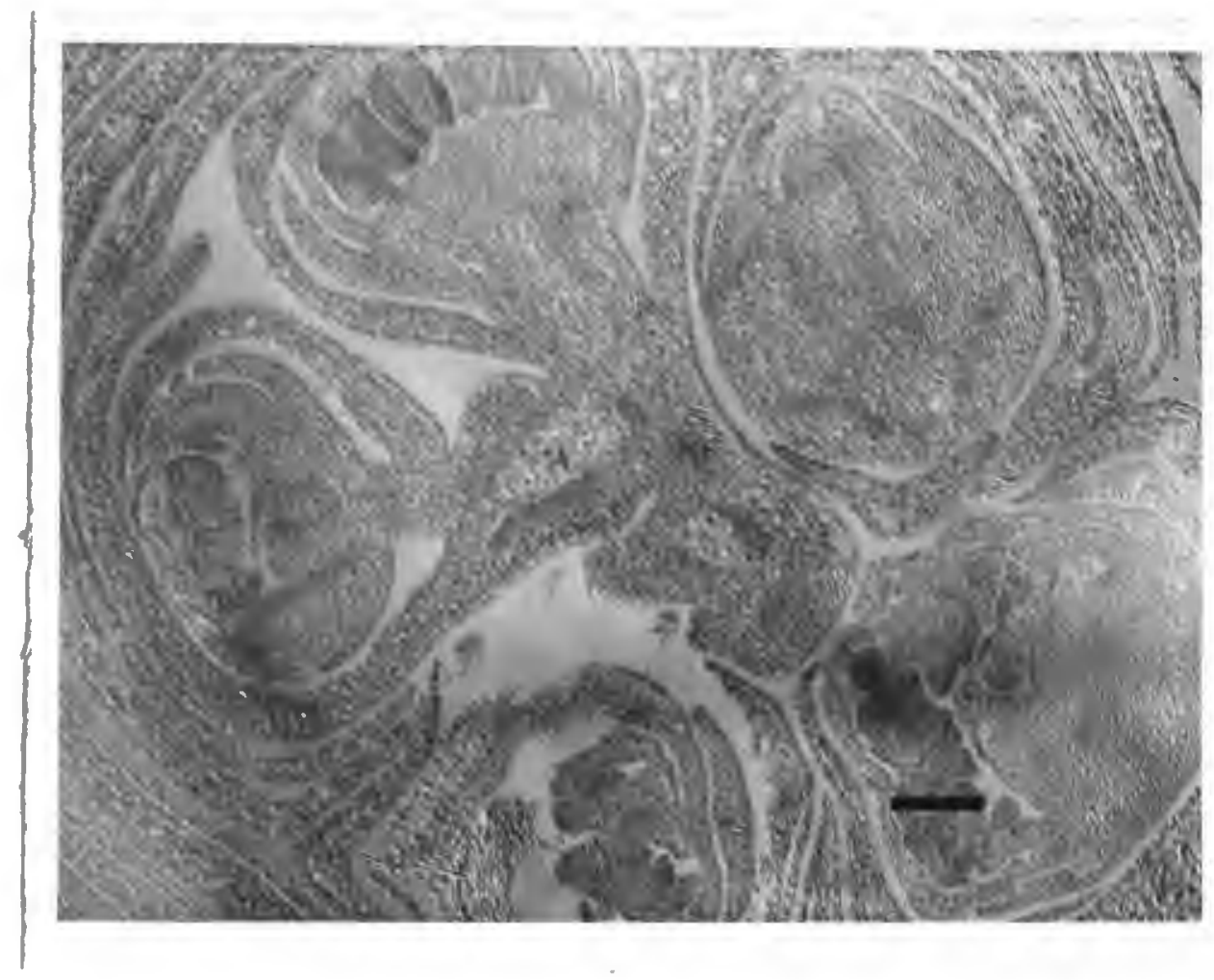


Figure 10. Light micrograph of a cross section of a 'Bluecrop' blueberry flower bud from a flooded plant. Note the delay in development and decreased overall size. Scale bar $=171 \mathrm{~mm}$. 


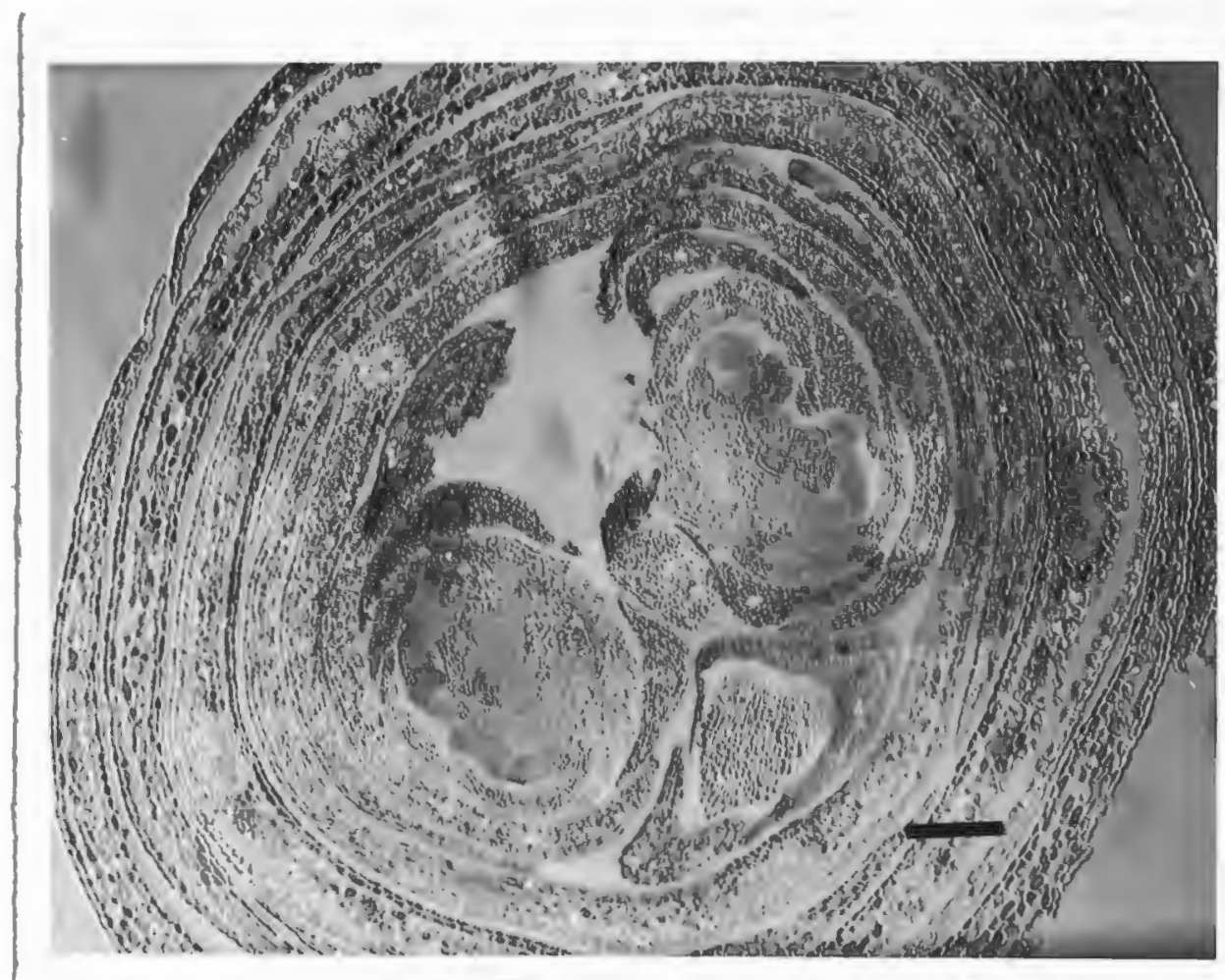


APPENDIX I

CONCLUDING REMARKS 
Previous researchers have stated that the cultivated highbush blueberry is not able to survive under flooded soil conditions. This idea has been promulgated as fact since the beginning of blueberry domestication approximately 80 years ago.

Prior to studying how flooding affects the growth of the highbush blueberry, I initiated a study to characterize the growth of roots in the field. The rate of root growth was found to peak in early-June and again in september when soil temperatures were in the range of 14 to $18^{\circ} \mathrm{C}$. These two time periods corresponded with the times that vegetative and reproductive growth were most affected by flooding. Plants flooded beginning in April exhibited the greatest decrease in vegetative and reproductive growth. Also, greater than $50 \&$ of those plants died within a few months. Plants flooded in August were intermediate in response between the April and December flooded plants. Shoot growth was decreased with flooding, primarily as a result of decreased internode elongation. Leaf size was decreased by reduced expansion. The reduction in leaf size coupled with stomatal closure would result in a decrease in photosynthesis and carbohydrate accumulation. This would limit the ability of the plant to produce new roots, replacing those decayed as a result of flooding. The 
overall reduction in vegetative growth caused by flooding ultimately affected the reproductive growth of the plant. Potential for fruit production was decreased due to a reduction in the number of flower buds formed, number of flowers produced per bud, and number of fruit set. There was a further decrease in fruit production on flooded plants as a result of increased abscision of those fruit that did set. Flooding also reduced fruit quality and yield by reducing fruit size, weight and the sweetness (soluble solids).

Although overall plant growth is reduced with flooding, the highbush blueberry is able to survive extended periods under flooded conditions. Anatomical examinations revealed that this may be a result of modifications in structure. The epidermal cells of the roots of flooded plants are largely expanded, the mid-cortical region of stems developed aerenchyma-like cells, and intercellular spaces within the spongy mesophyll complex of the leaves were increased These modifications, which have been noted in other plant species, could provide a mechanism by which oxygen diffuses more freely from the leaves and stems into the roots, thus reducing or eliminating the lack of oxygen in the flooded root zone. Prior knowledge indicated that flooded soil conditions would 
have adverse affects on the growth of the highbush blueberry, however the extent of the damage and the ability to survive was not known. This study was undertaken to elucidate those facts and it was found that there is indeed a detrimental effect of flooding on plant growth. However, the highbush blueberry can survive extended lengths of time under flooded conditions, which we noted in plants flooded beginning in December 1983. Those plants survived more than 26 months and flowered and produced fruit during that time.

This work leads to countless ideas for future related research all of which cannot be mentioned. The characteristics of root growth and factors affecting it could be further elucidated under controlled conditions. The roots could be placed under varying controlled temperatures to further define the optimum and threshold temperatures. Varying the degree of shoot and fruit removal would clarify their role in the growth of the roots. Also, a factor not examined inthis study, but one which should be looked at in relation to root growth, is water availability.

In addition, the effects of flooding and mechanisms of survival could be areas for future research. Modifications in plant metabolism, water relations, and hormonal response, 
although discussed, were not studied. 
APPENDIX II

RESULTS ANCILLARY TO MANUSCRIPT I 
Figure 1. Elongation of white unsuberized roots of highbush blueberry in relation to soil temperature and shoot growth (1982). 


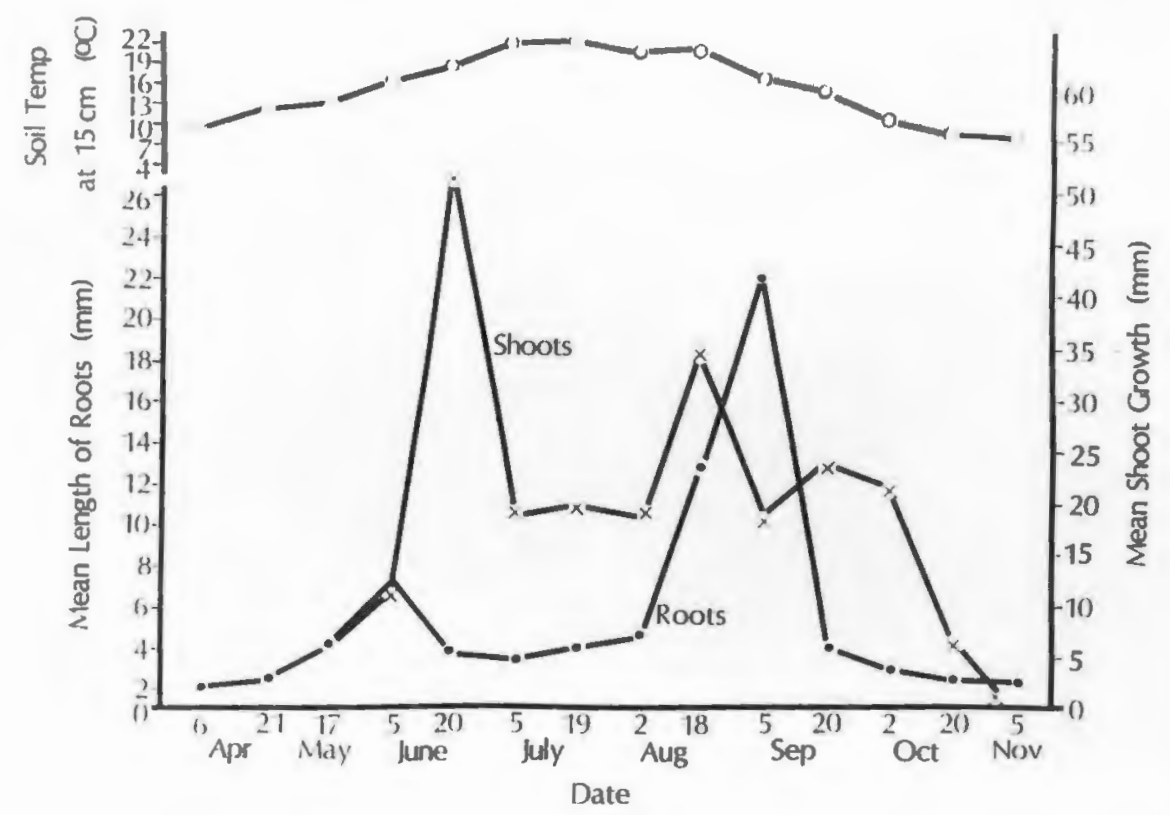


Figure 2. Elongation of white unsuberized roots of highbush blueberry in relation to soil temperature and shoot growth (1983). 


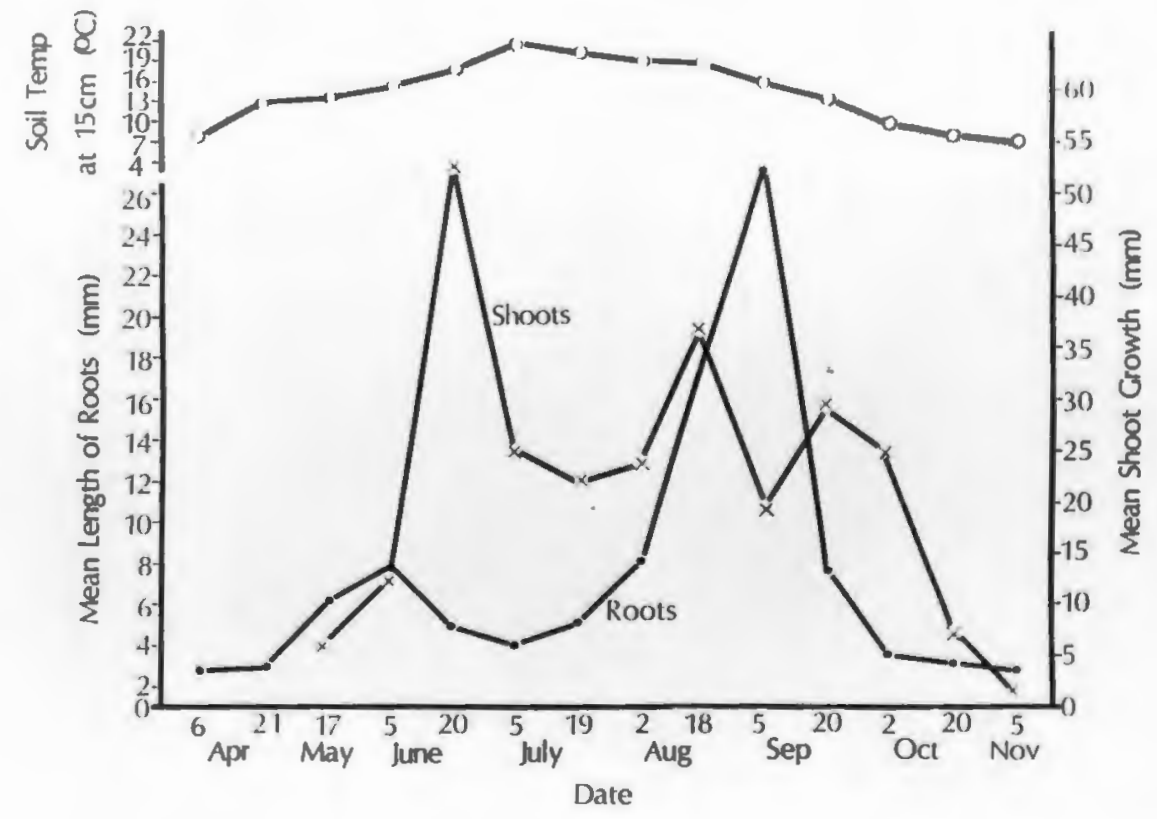


Figure 3. Elongation of white unsuberized roots of highbush blueberry in relation to soil temperature and shoot growth (1984). 


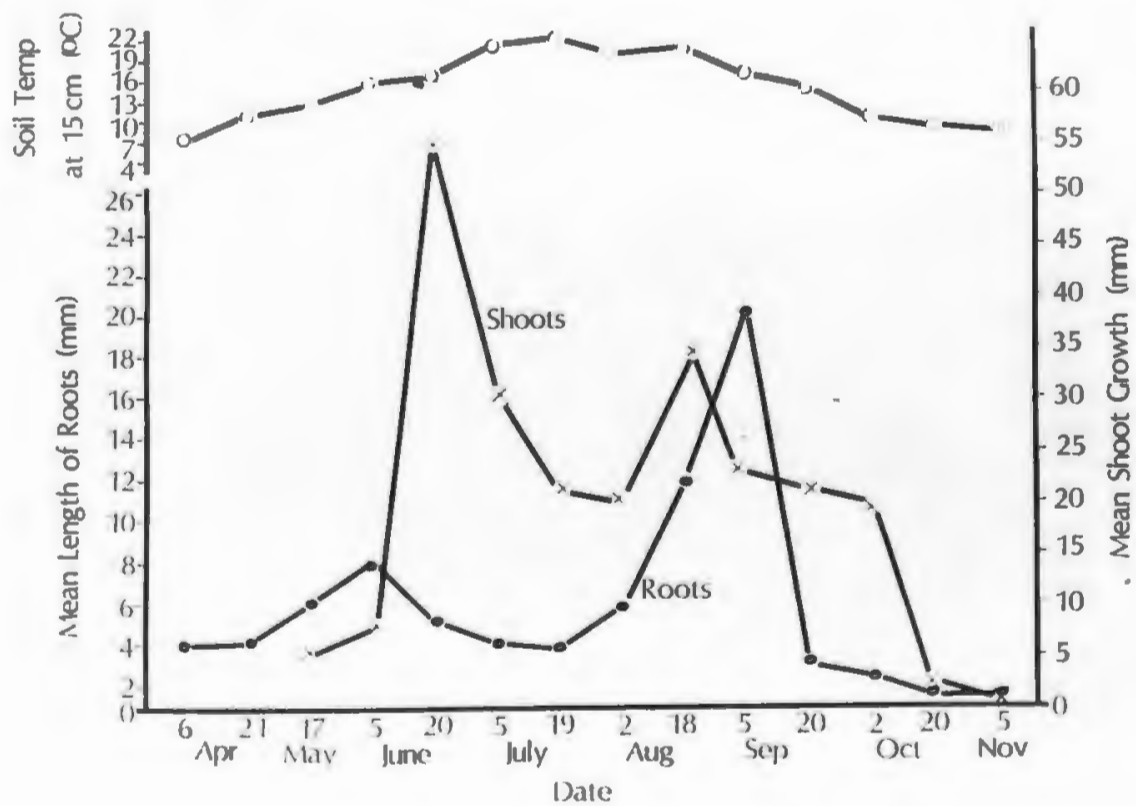


APPENDIX III

RESULTS ANCILLARY TO MANUSCRIPT II 
Table 1. Shoot growth of flooded and control two-year-old containerized 'Bluecrop' plants as affected by treatment date (November 1984).

\begin{tabular}{|c|c|c|c|c|c|c|c|c|c|}
\hline \multirow[b]{4}{*}{$\begin{array}{l}\text { Treatment } \\
\text { date }\end{array}$} & \multirow{2}{*}{\multicolumn{3}{|c|}{ Control }} & \multicolumn{3}{|c|}{ Treatment } & \multirow{2}{*}{\multicolumn{3}{|c|}{ Continuous flooding }} \\
\hline & & & & Floc & ded/olar & ted & & & \\
\hline & Shoot & & Internode & Shoot & & Internode & Shoot & & Internode \\
\hline & $\begin{array}{c}\text { length } \\
(\mathrm{am})\end{array}$ & $\begin{array}{l}\text { Nodes/ } \\
\text { shoot }\end{array}$ & $\begin{array}{c}\text { length } \\
(\mathrm{om})\end{array}$ & $\begin{array}{c}\text { length } \\
(\mathrm{cm})\end{array}$ & $\begin{array}{l}\text { Nodes/ } \\
\text { shoot }\end{array}$ & $\begin{array}{c}\text { length } \\
(\mathrm{cm})\end{array}$ & $\begin{array}{c}\text { length } \\
\text { (ani) }\end{array}$ & $\begin{array}{l}\text { Nodes/ } \\
\text { shoots }\end{array}$ & $\begin{array}{c}\text { length } \\
(\mathrm{cm})\end{array}$ \\
\hline Dec. 1983 & $3.5 \mathrm{a}^{\mathrm{z}}$ & $5 \cdot 3 b$ & $0.65 b$ & $3.7 \mathrm{~b}$ & $6.5 a$ & $0.57 a$ & $2.6 a$ & $6.2 a$ & $0.42 a$ \\
\hline Apr. 1984 & $6.7 a$ & $8.3 a$ & $0.81 \mathrm{a}$ & $1.6 \mathrm{c}$ & $4.8 \mathrm{~b}$ & $0.33 b$ & $1.5 b$ & $4.3 b$ & $0.35 a$ \\
\hline Ause. 1984 & 5.16 & $7.5 a$ & $0.68 \mathrm{~b}$ & $4.6 a$ & 6.92 & $0.67 \mathrm{a}$ & $2.8 a$ & $6.6 a$ & $0.42 a$ \\
\hline
\end{tabular}

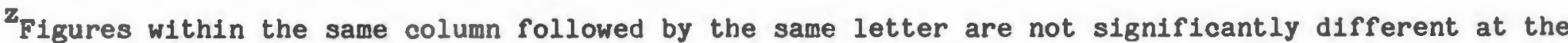
Duncan's Multiple Range Test. 
Table 2. Shoot growth of flooded and control two-year-old containerized 'Bluecrop' plants as affected by treatment date (November 1985).

\begin{tabular}{|c|c|c|c|c|c|c|c|c|c|}
\hline \multirow[b]{2}{*}{$\begin{array}{l}\text { Treatment } \\
\text { date }\end{array}$} & \multicolumn{3}{|c|}{ Control } & \multicolumn{3}{|c|}{ Ireatment } & \multicolumn{3}{|c|}{ Continuous flooding } \\
\hline & $\begin{array}{l}\text { Shoot } \\
\text { length } \\
\text { (am) }\end{array}$ & $\begin{array}{l}\text { Nodes/ } \\
\text { shoot }\end{array}$ & $\begin{array}{l}\text { Internode } \\
\text { length } \\
\text { (cm) }\end{array}$ & $\begin{array}{l}\text { Shoot } \\
\text { length } \\
\text { (am) }\end{array}$ & $\begin{array}{l}\text { Nodes/ } \\
\text { shoot }\end{array}$ & $\begin{array}{l}\text { Internode } \\
\text { length } \\
(\mathrm{cm})\end{array}$ & $\begin{array}{l}\text { Shoot } \\
\text { length } \\
(\mathrm{cm})\end{array}$ & $\begin{array}{l}\text { Nodes/ } \\
\text { shoots }\end{array}$ & $\begin{array}{l}\text { Internode } \\
\text { length } \\
(\mathrm{cm})\end{array}$ \\
\hline Dec. 1983 & $6.8 \mathrm{ab}^{\mathrm{z}}$ & $5.8 c$ & $1.17 a$ & $4.3 b c$ & $6.4 a$ & $0.66 c$ & $2.4 \mathrm{~b}$ & $5.7 \mathrm{bc}$ & $0.42 b$ \\
\hline Apr. 1984 & $5.8 c$ & $7.6 a$ & $0.76 d$ & $4.0 c$ & $4.6 c$ & $0.87 \mathrm{ab}$ & - & - & $-\mathbf{y}^{\mathbf{y}}$ \\
\hline Aus. 1984 & $6.2 b c$ & $7.4 a$ & $0.83 \mathrm{~cd}$ & $5 \cdot 3 a$ & $6.4 a$ & $0.83 \mathrm{ab}$ & $1.9 b$ & $6.3 a b$ & $0.30 \mathrm{bc}$ \\
\hline Dec. 1984 & $6.4 \mathrm{~b}$ & $6.9 a b$ & $0.93 b c$ & $5.7 a$ & $6.3 a$ & $0.91 a$ & $3.8 \mathrm{a}$ & $6.6 \mathrm{a}$ & $0.57 a$ \\
\hline Apr. 1985 & $6.1 \mathrm{bc}$ & $6.7 \mathrm{bc}$ & 0.91 bc & $4.2 b c$ & $5.3 b$ & $0.79 b$ & $1.1 \mathrm{c}$ & $5.1 \mathrm{c}$ & $0.22 c$ \\
\hline Aus. 1985 & $7.1 \mathrm{a}$ & $7.3 a$ & $0.98 \mathrm{~b}$ & $4.9 \mathrm{~b}$ & $6.2 a$ & $0.79 \mathrm{~b}$ & $3.8 a$ & $6.6 a$ & $0.57 \mathrm{a}$ \\
\hline
\end{tabular}

${ }^{z}$ Figures within the same column followed by the same letter are not significantly different at the 5\% level using Duncan's Multiple Range Test.

$\mathbf{y}_{\text {All plants died. }}$ 


\section{APPENDIX IV}

RESULTS ANCILLARY TO MANUSCRIPT III 
Table 1. Reproductive growth of flooded and control two-yearold containerized 'Bluecrop' plants as affected by date (1984).

\begin{tabular}{|c|c|c|c|}
\hline & Control & $\begin{array}{l}\text { Treatment } \\
\text { Flooded/ } \\
\text { lianted }\end{array}$ & $\begin{array}{c}\text { Continuous } \\
\text { clooding }\end{array}$ \\
\hline $\begin{array}{c}\text { Treatment } \\
\text { date }\end{array}$ & $\begin{array}{l}\text { No. flower } \\
\text { buds/shoot }\end{array}$ & $\begin{array}{l}\text { No. flower } \\
\text { buds/shoots }\end{array}$ & $\begin{array}{l}\text { No. flower } \\
\text { buds/shoot }\end{array}$ \\
\hline Dec. 1983 & $3 \cdot 3 b^{2}$ & $1.0 \mathrm{a}$ & $1.8 a$ \\
\hline Apr. 1984 & $6.8 a$ & $0.0 \mathrm{~b}$ & $0.0 c$ \\
\hline Aug. 1984 & $3.7 \mathrm{~b}$ & $0.6 a$ & $0.6 \mathrm{~b}$ \\
\hline
\end{tabular}

zFigures within the same column followed by the same letter are not significantly different at the $5 \%$ level using Duncan's Multiple Range Test. 
Table 2. Reproduotive growth of Plooded and control two-year-old containerjzed 'Bluecrop' plants as afrected by treatment date (1985).

\begin{tabular}{|c|c|c|c|c|c|c|c|c|c|c|c|c|}
\hline \multirow[b]{3}{*}{$\begin{array}{l}\text { Treatwent } \\
\text { date }\end{array}$} & \multicolumn{12}{|c|}{ Teaknent. } \\
\hline & \multicolumn{4}{|c|}{ Contreal } & \multicolumn{3}{|c|}{ Flooded/olanted } & \multicolumn{3}{|c|}{ Centilunous clooding } & \multicolumn{2}{|c|}{ Eruil gualtity } \\
\hline & $\begin{array}{c}\text { No. } \\
\text { rlower } \\
\text { budelahoot. }\end{array}$ & $\begin{array}{l}\text { No. } \\
\text { rlowers/ } \\
\text { hud }\end{array}$ & $\begin{array}{l}\text { Eruth } \\
\text { diam. } \\
(m \cdot 1)\end{array}$ & $\begin{array}{c}\text { quallty } \\
\text { sS } \\
(5)\end{array}$ & $\begin{array}{c}\text { No. } \\
\text { flower } \\
\text { budslshoet. }\end{array}$ & $\begin{array}{l}\text { No. } \\
\text { rlower/ } \\
\text { bud }\end{array}$ & $\begin{array}{l}\text { Ecult } \\
\text { d1an. } \\
\text { (mm) }\end{array}$ & $\begin{array}{c}\text { oualdty } \\
\text { ss } \\
\text { (u) }\end{array}$ & $\begin{array}{c}\text { No. } \\
\text { rlower } \\
\text { buds/shoots }\end{array}$ & $\begin{array}{l}\text { No. } \\
\text { rlowers/ } \\
\text { bud. }\end{array}$ & $\begin{array}{l}\text { Erulh } \\
\text { diam. } \\
(\mathrm{mm})\end{array}$ & $\begin{array}{c}\text { ouality } \\
\text { ss } \\
\text { (5) }\end{array}$ \\
\hline Dec. 1983 & $4.0 \mathrm{bo}^{\mathrm{y}}$ & $4.6 \mathrm{a}$ & $25.9 b$ & $11.5 \mathrm{a}$ & $2.0 \mathrm{a}$ & $5.0 \mathrm{a}$ & $10.2 \mathrm{c}$ & $8.7 \mathrm{c}$ & $0.9 \mathrm{~b}$ & $4.0 \mathrm{a}$ & $9.4 a b$ & $8.4 \mathrm{a}$ \\
\hline Apr. 1984 & $3 \cdot 3 c$ & $4.0 b$ & $17.8 \mathrm{a}$ & $11.8 \mathrm{a}$ & $0.9 \mathrm{~b}$ & $0.0 \mathrm{c}$ & $0.0 \mathrm{~d}$ & $0.0 \mathrm{~d}$ & $0.0 d$ & $0.0 \mathrm{~d}$ & $0.0 \mathrm{c}$ & $0.0 \mathrm{~b}$ \\
\hline Aug. 1984 & 4.36 & 4.16 & $17.9 a$ & $11.9 a$ & $0.9 b$ & $1.8 b$ & $10.5 \mathrm{c}$ & $9.6 \mathrm{bc}$ & $0.4 c$ & 0.30 & $10.2 \mathbf{a}$ & $9.3 a$ \\
\hline Deo. 1984 & $5.8 \mathrm{a}$ & $4.5 \mathrm{a}$ & $17.7 a$ & $11.6 \mathrm{a}$ & $2.1 \mathrm{a}$ & 1.80 & $16.5 a$ & $11.0 \mathrm{a}$ & $1.5 a$ & 1.16 & $10.2 \mathrm{a}$ & $8.9 a$ \\
\hline Apr. 1985 & $4.8 \mathrm{~b}$ & $-{ }^{x}$ & 16.66 & $12.19 a$ & $1.0 \mathrm{~b}$ & -2 & $14.2 b$ & $10.2 b$ & $0.0 \mathrm{~d}$ & $--^{x}$ & 8.76 & $8.6 a$ \\
\hline Anre 1985 & $3.5 a$ & $2^{x}$ & $-x$ & $-x$ & $2.3 \mathrm{a}$ & $=x$ & $-x$ & $-x$ & $1,6 a$ & $-x$ & $-x$ & $-x$ \\
\hline
\end{tabular}

soluble sol1ds.

YFigures within the same column rollowed by the same letter are not significantly dirferent at the $5 \$$ level using Duncan's Hudtiple Range Test.

Tota not avallable at time or measurement. 
Table 3. S1ze of rlower buds and flowers frow rlooded and control two-year-old oontalnerized 'Bluearop' plants as erfected by treatment date (1985).

\begin{tabular}{|c|c|c|c|c|c|c|c|c|c|c|c|c|}
\hline \multirow{2}{*}{$\begin{array}{l}\text { Troatwont } \\
\text { Date }\end{array}$} & \multicolumn{4}{|c|}{ Contreol } & \multicolumn{4}{|c|}{ Treatment } & \multicolumn{3}{|c|}{ Contsimuous cloodine } & \multirow[b]{2}{*}{ aten } \\
\hline & Elonen & ud alin & Elower & 20 & Eloyer & atre & Elos: & 29 & Elove & dolas & Eloner & \\
\hline Deo. 1983 & $4.8 a^{3}$ & $2.9 a$ & 4.10 & 2.10 & $4.6 a$ & $2.6 \mathrm{a}$ & $3.9 a$ & 2.00 & 4.18 & 2.02 & $3.7 a$ & $1.9 \mathrm{e}$ \\
\hline Apr. 1984 & $4.8 \mathrm{a}$ & 3.08 & $4.2 \mathrm{a}$ & $2.2 a$ & $4.4 a$ & $2.5 \mathbf{a}$ & - & - & 3.90 & $1.8 \mathrm{a}$ & - & - \\
\hline Aug. 1984 & $4.9 a$ & $3.0 \mathrm{a}$ & 4.3 & 2.28 & $4.3 a$ & $2.4 a$ & $3.9 a$ & $2.0 a$ & $3.8 \mathbf{a}$ & $1.9=$ & $3.8 \mathbf{a}$ & $1.9 a$ \\
\hline na. 19,2 & 5.14 & 3.12 & 1.21 & $2.1 \mathrm{.}$ & 1. & 2.62 & $3.9 n$ & $2.0 n$ & 3.7 & In & 3.72 & 1.9 \\
\hline
\end{tabular}

Spigures within the sase ooluma followed by the sawe letter are not algniflaantly difforent at the 58 level using Dunoan's Multiple Range Teat. 
Table 4. Initial \% fruit set and cumulative \& fruit abscised from flooded and control two-year-old containerized 'Bluecrop' plants as affected by treatment date.

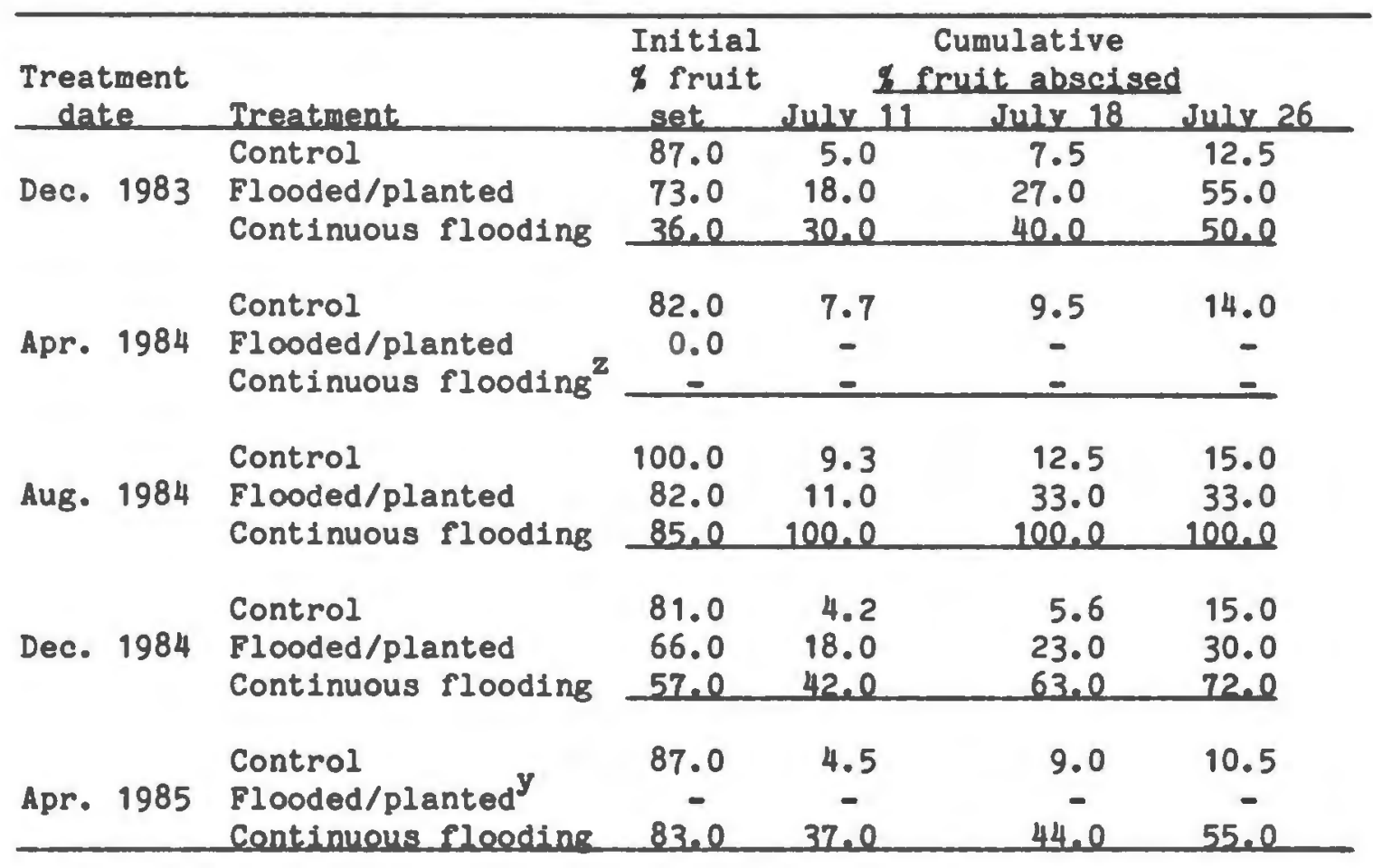

${ }^{2}$ All plants died.

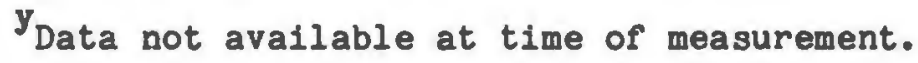


BIBLIOGRAPHY

Abbott, J.D. and R.E. Gough. 1986. Vegetative growth response and survival of the highbush blueberry to flooding. J. Amer. Soc. Hort. Sci. (In review).

Abbott, J.D. and R.E. Gough. 1986. Reproductive growth response of the highbush blueberry to flooding. Hortscience. (In review).

Andersen, P.C., P.B. Lombard, and M.N. Westwood. 1984. Leaf conductance, growth and survival of willow and deciduous fruit tree species under flooded soil conditions. J. Amer. soc. Hort. Sci. 109:132-138.

Armstrong, w. 1979. Aeration in higher plants. Adv. Bot. Res. $7: 225-332$.

Atkinson, D. 1972. Seasonal periodicity of black currant root growth and the influence of simulated mechanical harvesting. J. Hort. Sci. 47:165-172.

Atkinson, D. 1973. Seasonal changes in the length of white unsuberized root on raspberry plants grown under irrigated conditions. J. Hort. Sci. 48:413-419.

Atkinson, D. 1980. The distribution and effectiveness of the root of tree crops. Hort. Rev. 2:424-490.

Ball E. and C.E.T. Mann. 1927. Studies on the root and shoot development of the strawberry. J. Pomol. and Hort. Sci. $6: 87-103$.

Batjer, L.P., J.R. Magness, and L.O. Regeimbal. 1939. The effect of root temperature on growth and nitrogen intake of apple trees. Proc. Am. Soc. Hort. Sci. 37:11-18.

Berlyn, G.P. and J.P. Miksche. 1976. Botanical microtechnique and cytochemistry. The Iowa State University Press, Ames, Iowa.

Bhar, D.S., G.F. Mason, and R.J. Hilton. 1970. Insitu observations on plum root growth. J. Amer. Soc. Hort. Sci. $95: 237-239$.

Boynton, D. 1940. Soil atmosphere and the production of new 
rootlets by apple tree root systems. Proc. Am. Soc. Hort. Sci. 37:19-26.

Broadfoot, W.M. and H.L. Williston. 1973. Flooding effects in southern forests. J. For. 71:584-587.

Burrows, W.J. and D.J. Carr. 1969. Effects of flooding the root system of sunflower plants on the cytokinin content in the xylem sap. Physiol. Plant. 22:1105-1112.

Cain, J.C. and G.L. Slate. 1953. Blueberries in the home garden. Cornell Agr. Exp. Sta. Bull. 900.

Childers, N.F. and D.G. White. 1942. Influence of submersion of the roots on transpiration, apparent photosynthesis, and respiration of young apple trees. Plant Physiol. 17:603-618.

Childers, N.F., D.G. White, and H.W. Ford. 1943. Effect of ground water table on apparent photosynthesis and growth of apple trees. Proc. Am. Soc. Hort. Sci. 42:59-60.

Childers, N.F. 1983. Modern Fruit Science. Horticultural Publications, Gainesville, FL.

Crane, J.H. and F.S. Davies. 1985. Effects of flooding duration and season on rabbiteye blueberry growth and yield. HortScience 20:529 (Abstr.).

Davies, F.S. and D. Wilcox. 1984. Waterlogging of containerized rabbiteye blueberries in Florida. J. Amer. Soc. Hort. Sci. 109:520-524.

Davies, F.S. and J.A. Flore. 1986. Gas exchange and flooding stress of highbush and rabbiteye blueberries. J. Amer. Soc. Hort. Sci. In press.

Doehlert, C.A. 1937. Blueberry tillage problems and a new harrow. J. Agr. Exp. Sta. Bull. 625.

Drew, M.C., M.B. Jackson, and S. Gifford. 1979. Ethylene promoted adventitious rooting and development of cortical air spaces (aerenchyma) in roots may be adaptive responses to flooding in zea mays L. Planta. 147:83-88.

Eck, P. 1966. Botany. pp. 14-44. In: Eck, P. and N.F. Childers (eds.). Blueberry Culture. Rutgers Univ. Press, New Brunswick, N.J. 
Fraser, A.I. and I.B.H. Gardner. 1967. Rooting and stability in Sitka Spruce. U.K. Bull. Form. Comm. No. 40.

Gough, R.E., V.G. Shutak, and D.B. Wallace. 1983. Highbush blueberry culture. Rhode Island Coop. Ext. Ser. Bull. 143 (rev.).

Gough, R.E. 1980. Root distribution of 'Coville' and 'Lateblue' highbush blueberries under sawdust mulch. J. Amer. Soc. Hort. Sci. 105:576-578.

Gough, R.E. and V.G. Shutak. 1978. Anatomy and morphology of cultivated highbush blueberry. Rhode Island Agr. Exp. Sta. Bull. 423.

Gough, R.E. and V.G. Shutak. 1976. Effect of SADH on leaves of cultivated highbush blueberry. Hortscience 11:514-515.

Harris, G.H. 1930. The activity of apple and filbert roots especially during the winter months. Proc. Am. Soc. Hort. Sci. $26: 329-334$.

Hatton, R.G. and J. Amos. 1927. Experiments upon the removal of lateral growth on young apple trees in summer. The effect on stem and root development. J. Pomol. and Hort. Sci. $6: 61-71$.

Head, G.C. 1966. Estimationg seasonal changes in the quantity of white unsuberized root on fruit trees. J. Hort. Sci. 41:197-206.

Head, G.C. 1967. Effects of seasonal changes in shoot growth on the amount of unsuberized root on apple and plum trees. J. Hort. Sci. 42:169-180.

Head, G.C. 1969. The effects of fruiting and defoliation on seasonal trends in new root production on apple trees. J. Hort. Sci. 44:175-181.

Heinicke, A.J. 1932. The effect of submerging the roots of apple trees at different seasons of the year. Proc. Am. Soc. Hort. Sci. 29:205-207.

Heinicke, A.J. 1936. Root growth in young apple trees made shortly before and after defoliation. Proc. Am. Soc. Hort. Sci. 33:164-165.

Herath, H.M.E. and G.W. Eaton. 1968. Some effects of water table, $\mathrm{pH}$, and nitrogen fertilization upon growth and 
nutrient-element content of highbush blueberry plants. Proc. Am. Soc. Hort. Sci. 92:274-283.

I.orton, R.F. and D.J. osborne. 1967. Senescence, abscision, and cellulase activity in Phaseolus vulgaris. Nature (London) 214:1086-1088.

Jackson, M.B. and D.J. Campbell. 1976. Waterlogging and petiole epinasty in tomato: the role of ethylene and low oxygen. New Phytol. 76:21-29.

Jackson, M.B. and M.C. Drew. 1984. Effects of flooding on herbaceous plants. pp. 47-128. In: T.T. Kozlowski (ed.). Flooding and Plant Growth. Academic Press, Orlando, FL.

Jackson, W.T. 1955. The role of adventitious roots in recovery of shoots following flooding of the original root system. Am. J. Bot. 42:816-819.

Kawase, M. 1974. Role of ethylene in induction of flooding damage in sunflower. Physiol. Plant. 31:29-38.

Kawase, M. 1981. Anatomical and morphological adaptation of plants to waterlogging. Hortscience 16:30-34.

Kender, W.J. and W.T. Brightwell. 1966. Environmental Relationships. pp. 75-93. In: P. Eck and N.F. Childers (eds.). Blueberry Culture. Rutgers Univ. Press., New Brunswick, N.J.

Kennedy, H.E. 1970. Growth of newly planted water tupelo seedlings after flooding and siltation. For. Sci. $16: 250-256$.

Kinman, C.F. 1932. A preliminary report on root growth studies with some orchard trees. Proc. Am. Soc. Hort. Sci. $24: 220-224$.

Korcak, R.F. 1983. Root respiration and soil aeration status of blueberry (Vaccinium sp.). J of Plant Nutr. 6:283-289.

Kramer, P.J. 1940. Causes of decreased absorption of water by plants in poorly aerated media. Am. J. Bot. 27:216-220.

Luckwill, L.C. 1960. The physiological relationships of root and shoot. Sci. Hort. $14: 22-26$.

MacDaniels, L.H. and A.J. Heinicke. 1929. Pollination and other factors affecting the set of fruit, with special 
reference to the apple. Cornell Agr. Exp. Sta. Bull. 497.

Maggs, D.H. 1967. The reduction in growth of apple trees brought about by fruiting. J. Hort. Sci. 38:119-128.

Mahlstede, J.P. and D.P. Watson. 1952. An anatomical study of adventitious root development in stems of Vaccinium corymbosum. Bot. Gaz. 113:279-285.

Marth, P.C. and F.E. Gardner. 1939. Evaluation of variety peach seedling stocks with respect to "wet feet" tolerance. Proc. Am. Soc. Hort. Sci. 37:325-337.

McManmon, M. and R.M.M. Crawford. 1971. A metabolic theory of flooding tolerance. The significance of enzyme distribution and behaviour. New Phytol. 70:299-306.

MCPherson, D.C. 1939. Cortical air spaces in the roots of Zea mays L. New Phytol. 38:190-202.

Mullins, M.G. 1967. M-rphogenetic effects of roots and of some synthetic cytokii,ns in Vitis vinifera L. J. Exp. Bot. 18:206-214.

Nielsen, K.F. R.L. Halstead, and A.J. Maclean. 1961. The influence of soil temperature on the growth and mineral composition of corn, bromegrass, and potatoes. Soil Sci. Soc. Amer. Proc. 25:369-372.

Nightingale, G.T. 1935. Effects of temperature on growth, anatomy, and metabolism of apple and peach roots. Bot. Gaz. $96: 581-637$.

North, C.P. and A. Wallace. 1955. Soil temperature and citrus. Calif. Agric., Nov., p. 13.

Olien, W.C. 1984. Effects of excessively wet soil on apple. Ann. Rpt. Maine State Pomol. Soc. pp. 19-22.

Olien, W.C. 1983. Initial research on apple root stocks and water stress. Ann. Rpt. Maine State Pomol. Soc. pp. 23-29.

Pereira, J.S. and T.T. Kozlowski. 1977. Variations among woody angiosperms in response to flooding. Physiol. Plant. $41: 184-192$.

Peterson, T.A., W.C. Mueller, and L. Englander. 1980. Anatomy and ultrastucture of a Rhododendron root-fungus association. Can. J. Bot. 58:2421-2433. 
Railton, I.D. and D.M. Reid. 1973. Effects of Benzyladenine on the growth of waterlogged tomato plants. Planta III: $261-266$.

Raper, C.D., D.L. Osmond, M. Wann, and W.W. Weeks. 1978 . Interdependence of root and shoot activities in determining nitrogen uptake rate of roots. Bot. Gaz. 139:289-294.

Reid, D.M. 1977. Crop response to waterlogging. pp.251-287. In: Physiological aspects of crop nutrition and resistance. U.S. Gupta (ed.). Atma Ram, Delhi, India.

Rogers, W.S. 1932. Root studies III. Pear, gooseberry, and blackcurrant root systems under different soil fertility conditions, with some observations on root stock and scion effect in pears. J. Pomol. and Hort. Sci. 30:219-227.

Rogers, W.S. 1939. Root studies VIII. Apple root growth in relation to rootstock, soil, seasonal, and climatic factors. J. Pomol. 17:99-130.

Rowe, R.N. and D.V. Beardsell. 1973. Waterlogging of fruit trees. Hort. Abstr. 43:533-548.

Rowe, R.N. and P.B. Catlin. 1971. Differential sensitivity to waterlogging and cyanogenesis by peach, apricot, and plum roots. J. Amer. Soc. Hort. Sci. 96:306-308.

Salisbury, F.B. and C.W. Ross. 1978. Plant Physiology (2 ed.). Wadsworth Publishing Co., Belmont, CA.

Sass, J.E. 1951. Botanical microtechnique (2 ed.). Iowa State College Press, Ames, Iowa.

Sifton, H.B. 1945. Air space tissues in plants. Bot. Rev. $11: 108-143$.

Skene, K.G.M. and G.H. Kerridge. 1967. Effect of root temperature on cytokinin activity in root exudate of Vitis vinifera L. Plant Physiol. 42:1131-1139.

Skene, K.G.M. 1967. Gibberellin-like substances in root exudate of Vitis vinifera. Planta 74:250-262.

Tang, Z.C. and T.T. Kozlowski. 1982. Physiological, morphological, and growth responses of Platanus occidentalis seedlings to flooding. Plant Soil 66:243-255. 
Wample, R.L. and D.M. Reid. 1975. Effect of aeration on flood induced formation of adventitious roots and other changes in sunflower (Helianthus annuus L.). Planta $127: 263-270$.

Weller, F. 1971. A method for studying the distribution of absorbing roots of fruit trees. Exp. Agric. 7:351-361. 